\title{
Fluvial networks of the Iberian Peninsula: a chronological framework
}

\author{
Juan I. Santisteban ${ }^{\mathrm{a}, *}$, Lothar Schulte ${ }^{\mathrm{b}}$ \\ ${ }^{a}$ Department of Stratigraphy, University Complutense de Madrid. C/José Antonio Novais, 2, 28040-Madrid, Spain \\ ${ }^{\mathrm{b}}$ Department of Physical and Regional Geography and Laboratory of Landscape Research, University of Barcelona, \\ C/Montalegre 6-8, E-08001 Barcelona, Spain
}

\begin{abstract}
Knowledge of the evolution of Spanish fluvial networks has improved during recent years as more river systems have been studied and more geochronological data has become available. However, the chronological framework is a major issue as the range of applications is limited by methodological constraints and spatial coverage is sparse. Integration of 'absolute' dating methods with biostratigraphy and palaeomagnetism permits the recent evolution of these river systems to be reviewed. The timing of incision from the Late Neogene to the present varies between the major Iberian fluvial systems, depending on the substrata and tectonic settings. Early Pleistocene and older fluvial sequences in the core areas of the Iberian Peninsula provide a more extensive record of fluvial evolution and are better preserved than the terrace flights in the coastal lowlands. Middle Pleistocene sequences are well developed in most of the major river systems in Iberia, particularly those of the Tajo, Guadalquivir and Aguas River, and frequently represent the principal climatic cycles of that period, although tectonic and sea-level effects can also be seen. For Late Pleistocene to Holocene times, the scheme becomes more complex. Our review suggests that each river system has responded differently to local and regional climate control, glacial and periglacial processes in headwaters in high mountain areas, glacio-eustatic sea-level changes and local and regional tectonic patterns.
\end{abstract}

\section{Introduction}

The Iberian Peninsula is located in a very particular area of the world. It is the bridge between the Atlantic and Mediterranean domains and also between Europe and Africa; consequently, it is influenced by all these surrounding environments. Additionally, its geodynamic position, between the European, African and Atlantic plates, combined with its complex Alpine tectonic history, leads to considerable variation in lithological, structural and tectonic patterns from area to area. As a result the Iberian Peninsula is characterized by a high diversity of landscapes and geomorphic histories.

To the north, the Iberian Peninsula is bounded by the Pyrenean and Cantabrian mountains, which are composed of Mesozoic-Cainozoic rocks in the east and Palaeozoic rocks in the west. To the south, the Betic Range, composed of Palaeozoic, Mesozoic and Cainozoic rocks, forms its boundary. The western half of the peninsula is mostly composed of Palaeozoic rocks deformed during the Hercynian Orogeny and has relatively smooth and old landscapes (except for the Atlantic border), whereas the eastern half is mainly formed by Mesozoic rocks uplifted during the Alpine Orogeny and thus shows more youthful landscapes. Among these Hercynian and Alpine ranges there are Cainozoic basins that form much of the Spanish landscape and are characterized by hilly and smooth terrain sculptured by the fluvial network. The present-day Spanish fluvial network comprises six main fluvial basins (Ebro, Tajo, Guadiana, Guadalquivir, Júcar and Segura), most of their courses draining the Cainozoic basins, plus a high number of small fluvial systems developed in relation to the young coastal mountains like the Cantabrian (in the north) and the Betic (in the southeast).

The study of Spanish river terrace sequences began over two centuries ago. In 1799, Joseph Louis Proust described erosion and sedimentation processes and explained the development of the terraces of several rivers (Proust, 1799). Since the beginning of the 20th century, studies on fluvial geomorphology were substantially consolidated and 
integrated with glacial geomorphology (e.g. Nussbaum, 1946). During this period Hernández-Pacheco (1928) was the first to review of the principal rivers of Spain and their fluvial terraces. Since the 5th INQUA Congress in Madrid and Barcelona in 1957, the number of studies of fluvial chronosequences increased, as did the complexity of the methodology used. Thus research on fluvial terraces and landscapes became one of the most important topics in Spanish geomorphology. According to the report of García Ruiz (2001), some 193 papers were published between 1941 and 1998 on fluvial terraces and 'glacis'.

Despite these many publications, knowledge of recent fluvial systems is still fragmentary. For this reason, in this study we shall concentrate the five major basins: Ebro, Tajo, Guadalquivir, Guadiana and Duero. Additionally, we shall include data from the medium-sized River Aguas in SE Spain, due to the extensive chronological datasets available from that system. We shall exclude those systems in Iberia that have experienced basin infill and progressive accumulation during the Quaternary (e.g. the Guadix-Baza basin) and those river systems for which there are no published chronological data (Ter, Llobregat, etc.). We shall also exclude transitional fluvio-marine deposits such as in the Ebro delta (Somoza et al., 1998; Maestro et al., 2002) or on the SW Spanish continental shelf, in relation to the Guadiana and Guadalquivir estuaries (Dabrio et al., 1999, 2000; Hernández Molina et al., 2002; Boski et al., 2002; Fernández-Salas et al., 2003; Lobo et al., 2004).

We concentrate on chronological information and refer readers to original sources for other features like geological setting, sedimentological, archaeological or palaeontological information. Our purpose is to compile all the available chronological data for the long-term evolution of the selected fluvial systems and make an overall comparison between systems rather than documenting the detailed evolution of each basin. In dealing with archaeological sites, we always consider artefacts found within the terrace deposits and not, unless explicitly stated, those found upon their surfaces. The main geomorphological features of the fluvial basins and their surrounding mountain ranges can be found in regional syntheses like that coordinated by Gutiérrez-Elorza (1994), whereas geological information can be found in syntheses like those of Friend and Dabrio (1996), Gibbons and Moreno (2002) and Vera (2004).

\section{The Ebro drainage basin}

Modern work on the evolution of the Ebro drainage network (Fig. 1) started with studies of the Cinca, Segre and Noguera-Pallaresa rivers in the 1980s. Research by Sancho (1988), Peña (1988) and Peña and Sancho (1988) correlated the terrace sequences of those rivers and provided a chronology based on archaeological criteria. Studies of the Ebro itself have been few and have provided sparse chronological control (Gutiérrez-Elorza and Peña, 1994). It was not until the 1990s that more chronological data was provided for some sequences in the Ebro basin, using ${ }^{14} \mathrm{C}$, palaeomagnetism and OSL (Macklin and Passmore, 1995; Fuller et al., 1998; Sancho et al., 2003; Peña et al., 2004a, b).

Other studies have concentrated on the Late Pleistocene Holocene, like those of the Huerva River sequence (Andres et al., 2002; Peña et al., 2004c) and the regional synthesis of valley fill and slope sequences in the Ebro Basin (Gutiérrez-Elorza and Peña, 1998). These papers

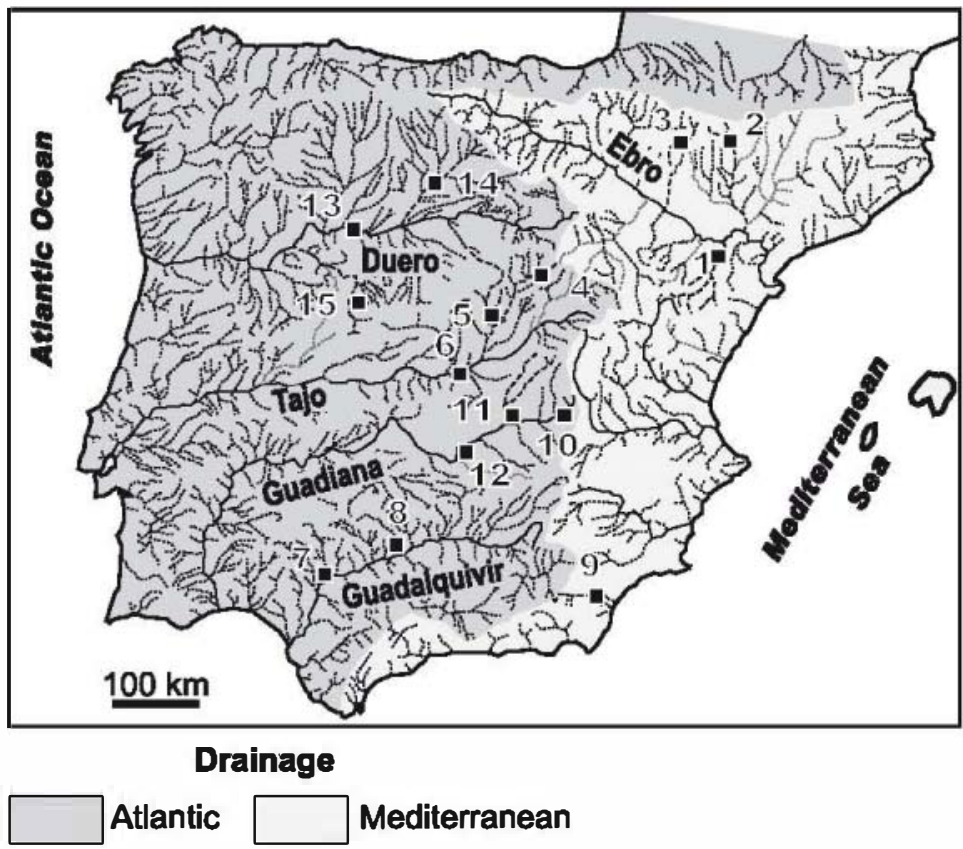

Ebro:

1. Guadalope

2. Cinca

3. Gállego

Tajo:

4. upper Henares

5. Henares-Manzanares-Jarama

6. Tajo

Guadalquivir:

7. Guadalquivir (Sevilla)

8. Guadalquivir (Córdoba)

SE:

9. Aguas/Antas

Guadiana:

10. Záncara

11. Guadlana-Glgùela

12. Guadiana

Duero:

13. Duero

14. Pisuerga

15. Tormes

Fig. 1. The Iberian drainage network and location of the presented terrace sequences. 


\begin{tabular}{|c|c|c|c|c|c|c|c|c|c|c|c|}
\hline & \multicolumn{3}{|c|}{ Fuller et al. (1998) } & \multicolumn{8}{|c|}{ Sancho et al. (2004), Peña et al. (2004a,b), McDonald et al. (2003), Sancho et al. (2003) } \\
\hline & \multicolumn{3}{|c|}{ Guadalope } & \multicolumn{5}{|c|}{ Cinca } & \multicolumn{3}{|c|}{ Gállego } \\
\hline & & & & \multicolumn{5}{|c|}{ upper-middle reach } & \multicolumn{3}{|c|}{ Alcalá de Gurrea } \\
\hline & & $H(m)$ & OSL & & $H(m)$ & magn. & OSL & ${ }^{14} \mathrm{C}$ & & $H(m)$ & OSL \\
\hline Hol. & & & & Qt10 & +0 & & & $2.5 \mathrm{kyr}$ & Qt10 & & \\
\hline \multirow{7}{*}{ 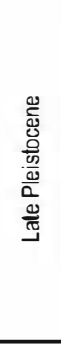 } & T11 & +4 & $18 \pm 5 \mathrm{kyr}$ & Qt9 & +4 & & $11.1 \pm 4 \mathrm{kyr}$ & $15.1 \mathrm{kyr}, 22.1 \mathrm{kyr}$ & Qt9 & & \\
\hline & $T 10$ & +9 & & & & & & & & & \\
\hline & T9 & +12 & $24 \pm 3$ kyr & & & & & & & & \\
\hline & T8 & +17.5 & & & & & & & & & \\
\hline & \multirow{3}{*}{$T 7$} & \multirow{3}{*}{+19} & \multirow{3}{*}{$\begin{array}{c}39 \pm 3 \mathrm{kyr} \\
48 \pm 4 \mathrm{kyr} \\
122 \pm 17 \mathrm{kyr}\end{array}$} & Qt8 & +13 & & $\begin{array}{c}41 \pm 8 \text { to } 49 \pm 4 \\
\text { kyr }\end{array}$ & & Qt8 & $+25-30$ & $31.6 \pm 4$ to $45 \pm 3 \mathrm{kyr}$ \\
\hline & & & & Qt7 & +34 & & $\begin{array}{c}53.8 \pm 3.3 \mathrm{to} \\
65.1 \pm 4.5 \mathrm{kyr}\end{array}$ & & Qt7 & $+35-40$ & $66 \pm 4$ to $73 \pm 10 \mathrm{kyr}$ \\
\hline & & & & Qt6 & +60 & \multirow{5}{*}{ Brunhes } & $97 \pm 16 \mathrm{kyr}$ & & Qt6 & $+45-50$ & \\
\hline \multirow{5}{*}{ 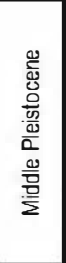 } & T6 & +23 & $157+15 /-14 \mathrm{kyr}$ & Qt5 & +80 & & $\begin{array}{l}176 \pm 14 \mathrm{kyr} \\
177 \pm 22 \mathrm{kyr} \\
180 \pm 12 \mathrm{kyr}\end{array}$ & & Qt5 & +75 & $\begin{array}{c}148 \pm 7 \text { to } \\
156 \pm 22 \mathrm{kyr}\end{array}$ \\
\hline & \multirow{4}{*}{$\begin{array}{l}\text { T4 } \\
\text { T3 }\end{array}$} & \multirow{2}{*}{\multicolumn{2}{|c|}{+29}} & Qt4 & +91 & & & & Qt4 & +100 & \\
\hline & & & & & & & & & & & \\
\hline & & \multirow{2}{*}{\multicolumn{2}{|c|}{$\begin{array}{l}+34 \\
+45\end{array}$}} & Qt3 & +103 & & & & Qt3 & +140 & \\
\hline & & & & & & & & & & & \\
\hline \multirow{3}{*}{ 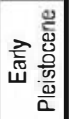 } & \multirow{3}{*}{$\begin{array}{l}\mathrm{T} 2 \\
\mathrm{~T} 1\end{array}$} & \multirow{3}{*}{\multicolumn{2}{|c|}{$\begin{array}{l}+56 \\
+81\end{array}$}} & $Q+2$ & +132 & Matuyama & & & $Q t 2$ & +170 & \\
\hline & & & & & & & & & & & \\
\hline & & & & Qt1 & +182 & & & & & & \\
\hline
\end{tabular}

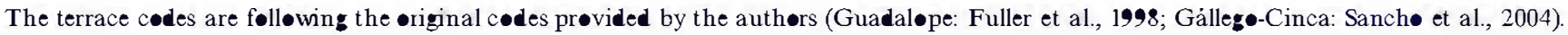

focus on the influence of human impact on sedimentation rates. In addition, there have been dating studies of travertine deposits related to the fluvial courses in the Ebro basin or nearby areas (Torres et al., 1995; Peña et al., 2000; Lozano et al., 2004) spanning 212 6 ka.

Amongst all the dated sequences, the longest records are those of the Gállego, Cinca and Guadalope rivers (Table 1, Fig. 2).

\subsection{Early Pleistocene}

Data on Early Pleistocene Ebro Basin fluvial history are scarce (Table 1, Fig. 2). However, magnetostratigraphy allows the Early Pleistocene Middle Pleistocene boundary in the Cinca River sequence to be placed between terraces Qt2 (reverse polarity, Matuyama) and Qt3 (normal polarity). From Qt3 to Qt6 all sampled terraces show normal polarity (Brunhes). The proposed morphostratigraphical correlation of these terraces (McDonald et al., 2003; Sancho et al., 2004; Peña et al., 2004a, b) allows extrapolation of this boundary to the Gállego River. Benito et al. (1998a) attributed the $+120 \mathrm{~m}$ terrace of the Gállego River (in an intermediate position between the Qt3 and Qt4 terraces, according to the stratigraphy of Sancho et al., 2004, and Peña et al., 2004a) to the Matuyama chron and the $+4050 \mathrm{~m}$ terrace to the Brunhes chron.

Estimates for the age of soils related to the $+115120 \mathrm{~m}$ terrace (intermediate between Qt3 and Qt2) of the Cinca
River by Lewis et al. (1999) and Sancho et al. (2000), and those of McDonald et al. (2003) for the soils of the Qt3 terrace, all agree in placing the Matuyama/Brunhes boundary between the Cinca Qt2 and Qt3 terraces. Consequently, Gállego terrace Qt2 (Peña et al., 2004a; Sancho et al., 2004) and Cinca Qt1 to Qt2 (Sancho et al., 2004; Peña et al., 2004a, b) must be of Early Pleistocene age. On this basis, the magnetic reversed field found by Benito et al. (1998a) in their $+120 \mathrm{~m}$ terrace (in an intermediate position between the Qt3 and Qt4 terraces) should be reinterpreted as the Emperor subchron ( $\sim 20 \mathrm{ka}$ ). The absence of chronological evidence forced Macklin and Passmore (1995) to consider terraces T1 to T5 of the Guadalope River as Middle Pleistocene or older.

\subsection{Middle Pleistocene}

The Middle Pleistocene Ebro Basin sequence is better constrained in time (Table 1, Fig. 2). The oldest terrace from this period is the Qt3 terrace of the Cinca and Gállego rivers, according to magnetostratigraphical data provided by Sancho et al. (2004). But the oldest region-wide preserved morphological level is the $+100 \mathrm{~m}$ terrace in the Gállego (Qt4: Peña et al., 2004a; +75/ + $100 \mathrm{~m}$ terrace: Benito et al., 1998a), equivalent to the $+6473 \mathrm{~m}$ terrace in the Ebro valley (Zuidam et al., 1975; Soriano, 1986), the $+8090 \mathrm{~m}$ terrace of the Segre river (Peña, 1988) and the + $8590 \mathrm{~m}$ (Peña and Sancho, 1988) and +91 m (Qt4, Peña 


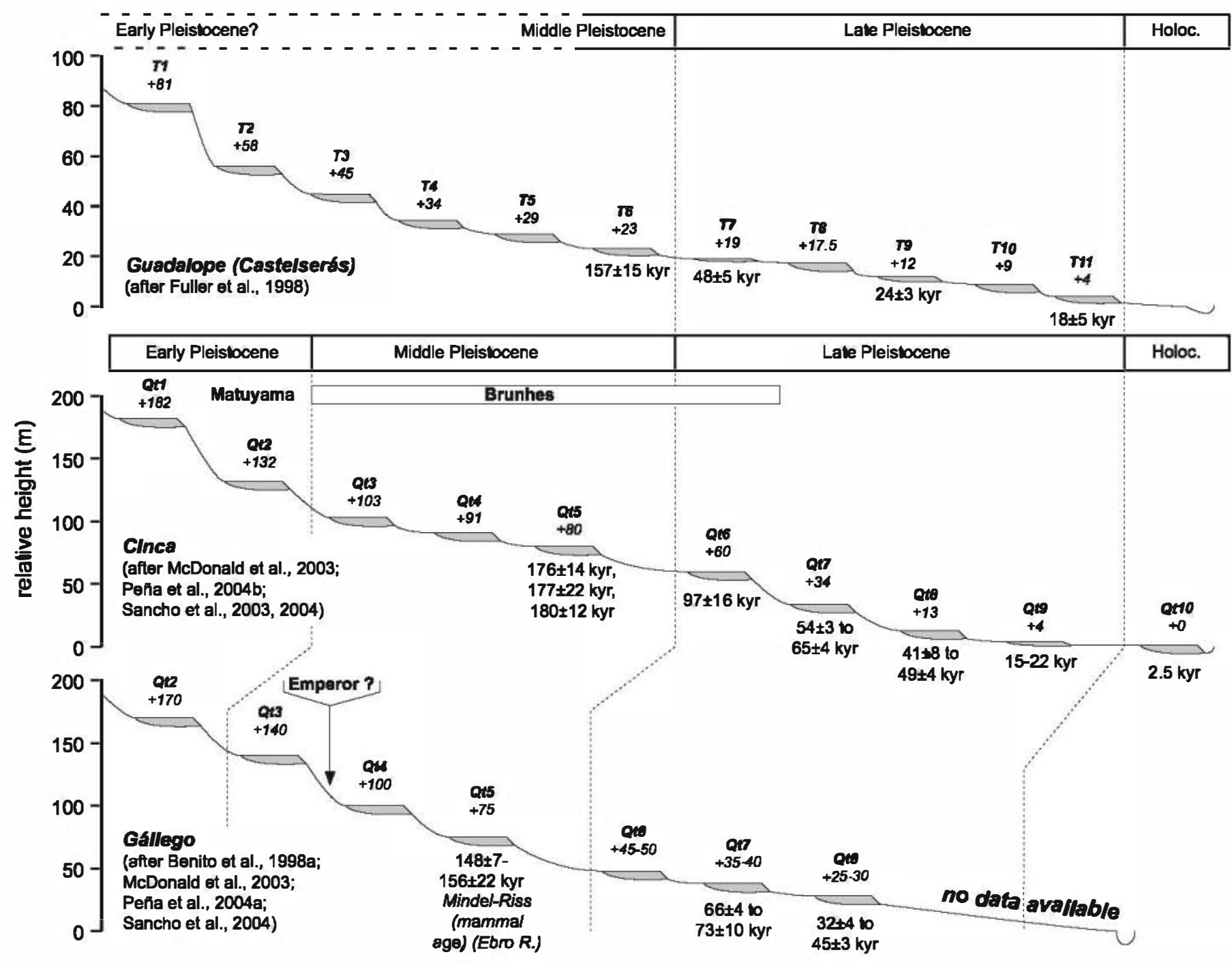

\section{Key for figures 2 to 7 :}

\begin{tabular}{|c|c|c|c|}
\hline$\Longleftarrow$ : Merrace level & $\begin{array}{c}\text { Q66 } \\
+45.50\end{array}$ & $\begin{array}{l}\text { : terrace level nomenclature } \\
\text { : relative height above thalweg }\end{array}$ & $97 \pm 16 \mathrm{kyr}$ : radlometric age plus uncertalnty range \\
\hline
\end{tabular}

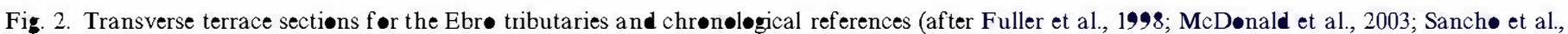

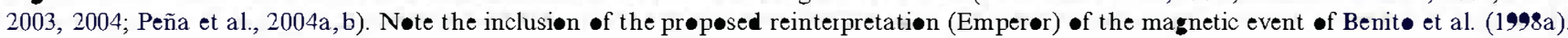

et al., 2004b; Sancho et al., 2004) terraces of the Cinca River. The Middle Pleistocene age of these terraces is derived from palaeomagnetic data (Brunhes chron: Sancho et al., 2004).

The Middle Pleistocene sequence of the Gállego River is composed of three terraces in the upper reach (Fig. 2, Table 1; Qt3 Qt5, +140 to $+75 \mathrm{~m}$ according to Peña et al., 2004a) and in the lower reach (T7 T9, from +70 to $+30 \mathrm{~m}$ according to Benito et al., 1998a). Chronological control is provided by the correlation of Qt4 with the $+6473 \mathrm{~m}$ terrace of the Ebro ("Mindel-Riss interglacial": Zuidam et al., 1975) and the OSL age for the Qt5 terrace of $156 \pm 22148 \pm 7$ ka (Peña et al., 2004a). Reinterpretation of the magnetic reversed field, discussed above, at the $+120 \mathrm{~m}$ Gállego terrace of Benito et al. (1998a) provides an age of $\sim 420 \mathrm{ka}$ (Emperor subchron). Chronological constraints are provided for the Cinca River by the ascription of terraces Qt3 Qt5 to the Brunhes chron (Sancho et al., 2000) and by OSL ages of between $176 \mathrm{ka}$ and $180 \mathrm{ka}$ obtained from Qt5 (Peña et al., 2004b; Sancho et al., 2004; Fig. 2, Table 1). The first chronological reference point for the Guadalope sequence is the $130 \pm 15 \mathrm{ka}$ to $183+39 /-37 \mathrm{ka}$ age for terrace T2 at Mas de Las Matas (Fuller et al., 1998), which correlates with T6 at Castelserás (157+15/-14 ka: Fuller et al., 1998; Fig. 2, Table 1). However, Macklin et al. (2002) considered only the $183+39 /-37 \mathrm{ka}$ age and placed this aggradation in marine Oxygen Isotope Stage (MIS) 67.

The Middle to Late Pleistocene boundary is very well constrained in the Guadalope and Cinca basins. In the 
Guadalope, terrace T6 is dated to $157 \mathrm{ka}$ (Fuller et al., 1998; Macklin et al., 2002) while the oldest age for T7 is $122 \pm 17 \mathrm{ka}$. In the Cinca basin, OSL dating places this boundary between Qt5 (176 $\pm 14 \mathrm{ka})$ and Qt6 (97 $\pm 16 \mathrm{ka})$ (Peña et al., 2004b), whereas in the Gállego basin its position is less well defined. The suite Qt5 Qt6 is considered to be $18083 \mathrm{ka}$ (McDonald et al., 2003) and Qt5 is dated $156148 \mathrm{ka}$ (Peña et al., 2004a). In addition, the Qt7 level of the Gállego has been dated as $6552 \mathrm{ka}$ (McDonald et al., 2003) or 73 66ka (Peña et al., 2004a).

\subsection{Late Pleistocene and Holocene}

The Pleistocene Holocene boundary, like the Early Pleistocene Middle Pleistocene boundary, is not well placed (Table 1, Fig. 2). In the Guadalope sequence, the youngest terrace ( $\mathrm{T} 11,+4 \mathrm{~m}$ ) corresponds to $18 \pm 5 \mathrm{ka}$ and, consequently, valley bottom deposits can span part of MIS 2 and MIS 1 . In the Cinca, ${ }^{14} \mathrm{C}$ dates of the Qt9 terrace point to a Late Pleistocene age (22 $15 \mathrm{ka})$ while a single OSL date reaches the base of the Holocene $(11.1 \pm 4 \mathrm{ka})$ (Sancho et al., 2004). In addition, Peña et al. (2004c) found at least three incised levels of Holocene age $(6015 \pm 75 \mathrm{yr}$ B.P.) in the Huerva River and explained the fluvial evolution of recent millennia in terms of climate and human impact.

\section{The Tajo (Tagus) draiuage basiu}

Fluvial sequences of the Tajo (Fig. 1) offer wider possibilities for dating as, in contrast to the other basins, they contain relatively frequent palaeontological remains. Therefore, radiometric dating can be compared with biostratigraphical data (Table 2, Fig. 3).

The classic sequences in the Tajo basin are those of the Jarama, Henares and Manzanares rivers near their confluence (Fig. 1). These sequences show the highest number of terraces and are rich in palaeontological sites. In addition, palaeomagnetic studies in the Tajo River, plus the dating of travertine deposits related to the upper Henares (Benito et al., 1998b), Trabeque, Escabas and Guadiela rivers (Torres et al., 1994a), provide further constraint on the chronology of the sequences. PérezGonzález (1994) provided a summary of the geomorphology and regional setting of the fluvial deposits of the Tajo basin, while archaeological and palaeontological information can be found in the work of Santonja and PérezGonzález (2000 2001).

\subsection{Early Pleistocene}

The only data available to establish the Early Middle Pleistocene boundary in the Tajo is defined near Toledo, where Pinilla et al. (1995) placed the Matuyama/Brunhes boundary at the +60 terrace (Table 2, Fig. 3). Additionally, Torres et al. (1994a) used aminochronology to date the travertine of the +90 terrace of the Trabeque-Escabas-
Guadiela rivers to $733 \pm 140 \mathrm{ka}$, at the beginning of the Bruhnes chron, and Silva et al. (1999) found remains of Mammuthus meridionalis (Early Pleistocene) in a terrace equivalent to the +8085 terrace of the Manzanares River. The wider recognition of this boundary can be achieved by regional correlation of terraces.

There are no dates for the uppermost terraces except the results of Torres et al. (1994b), who found a deposit with reversed polarity within fluvio-karstic sediments that they correlate with the Jarama terraces, without mention of the precise Jarama level. They attribute the unit to the GaussMatuyama transition. However, the absence of continuity in magnetic measurements below and the lack of magnetic studies in the uppermost deposits raise questions about the ascription of this level to the Gauss chron or to any of the Matuyama subchrons (Jaramillo, Olduvai).

In any case, the Early Pleistocene (or older) sequence is made up of 12 (Henares) to 2 (Manzanares) terrace levels, with a height range of $134 \mathrm{~m}$ in the case of the Henares River sequence.

\subsection{Middle Pleistocene}

Middle Pleistocene sequences are the richest in chronological markers due to the abundance of palaeontological sites (Table 2, Fig. 3). However, the Middle Pleistocene Late Pleistocene boundary is somewhat poorly defined. Dating of travertines in the $+30 \mathrm{~m}$ terrace of the Trabeque-Escabas-Guadiela rivers (Torres et al., 1994a) and the $+1820 \mathrm{~m}$ terrace of the upper Henares River (Benito et al., 1998b) provides ages ranging from $156 \pm 8$ to $90.9 \pm 5.4 \mathrm{ka}$ and $135 \pm 12$ to $103 \pm 8 \mathrm{ka}$, respectively. Luminescence samples from the $+20 \mathrm{~m}$ terrace of the Tajo River at Talavera de la Reina have dated this terrace as Late Pleistocene (Santonja and Pérez-González, 1997). Consequently, we place the Middle Pleistocene Late Pleistocene boundary at the bottom of the T19 terrace (Fig. 3) and, therefore, the Middle Pleistocene sequence comprises six terrace levels.

Other chronological reference points include $\mathrm{U} / \mathrm{U}$ and $\mathrm{Th} / \mathrm{U}$ dating of travertine samples of the $+4045,+3035$ and $+2025 \mathrm{~m}$ levels of the upper Henares River as $>350 \mathrm{ka}, 444 \pm 70 \mathrm{ka}$ and $202 \pm 58$ to $243 \pm 18 \mathrm{ka}$ respectively (Benito et al., 1998b). Mammal associations also provide ages for the $+4042 \mathrm{~m}$ terrace of the Jarama River, the $+2530 \mathrm{~m}$ terrace of the Manzanares River, and the $+4045 \mathrm{~m}$ and $+30 \mathrm{~m}$ terraces of the Tajo at Talavera de la Reina as $350300 \mathrm{ka}$, MIS 1311 and $550130 \mathrm{ka}$ respectively (Pérez-González, 1994; Sesé and Soto, 2000; Santonja and Pérez-González, 2000 2001). Of these data, only the $350300 \mathrm{ka}$ date is doubtful, as it is younger than the age provided for the Manzanares $+2530 \mathrm{~m}$ (MIS 13 11) and Henares $+3035 \mathrm{~m}$ (444ka) terraces, which correlate with the $+32 \mathrm{~m}$ level of the Jarama (Table 2).

In addition to the comparison of ages obtained from radiometric dating, correlation between river terraces is achieved by means of elevation above the thalweg 


\begin{tabular}{|c|c|c|c|c|c|c|c|c|c|c|c|c|}
\hline & \multicolumn{11}{|c|}{ Pérez-González (1994), Santonja \& Pérez-González (1997), Benito et al. (1998b), Sitva et al. (1999), Santonja \& Pérez-González (2000-2001) } \\
\hline & & \multicolumn{4}{|c|}{ Henares } & \multirow{2}{*}{$\begin{array}{c}\text { Manzanares } \\
\mathrm{H}(\mathrm{m})\end{array}$} & \multirow{2}{*}{$\begin{array}{c}\text { Jarama } \\
H(m)\end{array}$} & \multirow[b]{2}{*}{ paleon., age } & \multicolumn{4}{|c|}{ Tajo } \\
\hline & & $H(m)$ & $H(m)$ & paleon. & dates & & & & $H(m)$ & magn. & $H(m)$ & age \\
\hline & & & $\begin{array}{l}\text { upper } \\
\text { reach }\end{array}$ & & 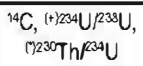 & & & & \multicolumn{2}{|c|}{ Toledo } & \multicolumn{2}{|c|}{ Talavera de la Reina } \\
\hline \multirow{2}{*}{$\begin{array}{l}\text { 혀 } \\
\text { 오 }\end{array}$} & $\mathrm{T} 23$ & & $+1-2$ & & & $+1-1.5$ & & & & & & \\
\hline & T22 & $+4-5$ & +4 & & $\begin{array}{c}6210 \pm 85 \mathrm{BP} \text { to } \\
9940 \pm 120 \mathrm{BP}\end{array}$ & $+4-5$ & $+3-5$ & & $+3-5$ & & $+3-5$ & \\
\hline \multirow{3}{*}{ 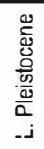 } & $\mathrm{T} 21$ & +7.9 & +9 & & & +8 & +8 & OIS 2 & $+4-6$ & & $+7-9$ & \\
\hline & $\mathrm{T} 20$ & $+10-12$ & & & & +10 & $+12-14$ & Cervus elaphus & & & & \\
\hline & T19 & $+18-20$ & +15 & & $\begin{array}{l}103 \pm 8 \mathrm{kyr}^{+} \\
135 \pm 12 \mathrm{kyr}^{+}\end{array}$ & $+12-15$ & $\begin{array}{c}+17-18 \\
+22\end{array}$ & & +20 & & +20 & L.Pleist. \\
\hline \multirow{6}{*}{ 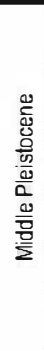 } & T18 & $+23-24$ & $+20-25$ & $\begin{array}{c}\text { Elephas sp., } \\
\text { Equus sp. }\end{array}$ & $\begin{array}{l}202 \pm 58 \mathrm{kyr} \\
243 \pm 18 \mathrm{kyr}\end{array}$ & $+18-20$ & +26 & $\begin{array}{l}\text { Elephas } \\
\text { antiquus }\end{array}$ & & & & \\
\hline & T17 & $+30-32$ & $+30-35$ & & $444 \pm 70 \mathrm{kyr}^{+}$ & $+25-30$ & +32 & $\begin{array}{c}\text { OIS 11-13 } \\
\text { (mammals) }\end{array}$ & & & & \\
\hline & T16 & $+38-40$ & $+40-45$ & & $>350 \mathrm{kyr}$ & $\begin{array}{l}+35-40 \\
+44-46\end{array}$ & $+40-42$ & $\begin{array}{l}300-350 \mathrm{kyr} \\
\text { (mammals) }\end{array}$ & +30 & & +30 & 畹 \\
\hline & T15 & $+52-54$ & $+50-55$ & & & $+52-54$ & +54 & & +40 & & $+40-45$ & \\
\hline & T14 & $+66-68$ & & & & +60 & +64 & & +50 & & & \\
\hline & $\mathrm{T} 13$ & $+70-72$ & & & & $+68-72$ & +74 & & +60 & $\begin{array}{c}\text { Brunhes/ } \\
\text { Matuyama }\end{array}$ & $+60-65$ & \\
\hline \multirow{12}{*}{ 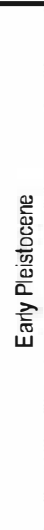 } & T12 & +78 & & & & $+80-85$ & $+84-86$ & $\begin{array}{l}\text { Mammuthus } \\
\text { meridionalis }\end{array}$ & $+75-80$ & & $+75-80$ & \\
\hline & T11 & +94 & & & & +95 & +92 & & +85 & & & \\
\hline & T10 & $+104-108$ & & & & & $+100-104$ & & +95 & & $+95-100$ & \\
\hline & $\mathrm{Tg}$ & $+116-118$ & & & & & $+110-114$ & & +105 & & +105 & \\
\hline & T8 & $+124-126$ & & & & & $+125-130$ & & +115 & & $+115-120$ & \\
\hline & $\mathrm{T7}$ & $+144-146$ & & & & & $+140-145$ & & +125 & & +130 & \\
\hline & T6 & +155 & & & & & $+150-155$ & & & & +155 & \\
\hline & $T 5$ & +172 & & & & & +170 & & & & +185 & \\
\hline & $\mathrm{T} 4$ & $+180-184$ & & & & & +180 & & & & & \\
\hline & $\mathrm{T} 3$ & $+190-195$ & & & & & +190 & & & & & \\
\hline & $\mathrm{T} 2$ & $+200-202$ & & & & & & & & & & \\
\hline & $\mathrm{T} 1$ & $+210-212$ & & & & & & & & & & \\
\hline
\end{tabular}

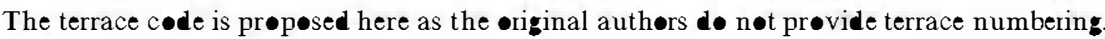

(Henares, Jarama and Manzanares rivers and Tajo and Alagón rivers) (Table 2, Fig. 3) or by biostratigraphical correlation (Santonja and Pérez-González, 2000 2001).

\subsection{Late Pleistocene and Holocene}

As in the Ebro Basin, the Pleistocene Holocene boundary is not clearly defined in the Tajo drainage system (Table 2, Fig. 3). Torres et al. (1994a) dated the $+20 \mathrm{~m}$ terrace of the Trabeque-Escabas-Guadiela rivers as $18.2 \pm 1.4$ to $10.5 \pm 4.7 \mathrm{ka}(\mathrm{Th} / \mathrm{U})$. Gladfelter $(1971,1972)$ and Preece (1991) provided ${ }^{14} \mathrm{C}$ ages between $9940 \pm 120$ and $6210 \pm 85 \mathrm{BP}$ for the $+4 \mathrm{~m}$ terrace of the upper Henares River. Therefore, the boundary can be placed in terrace T21 or between T21 and T22. The latter option is supported by the finding of Upper Palaeolithic lithic industries at the top (El Sotillo site) of the $+\mathbf{8 m}$ terrace of the Manzanares River (Santonja and Pérez-González,
2000 2001). Taking this as correct, the Late Pleistocene sequence will be composed of 2 to 3 terraces (usually lacking the intermediate) with a total height range of about $1114 \mathrm{~m}$.

The Holocene record comprises 2 terraces near the valley bottom. However, in some instances, Late Pleistocene sequences have accumulated to considerable heights. Benito et al. (2003) described slack-water deposits in the Tajo River near El Puente del Arzobispo, where the Holocene deposits rest upon Late Pleistocene $(14,090 \pm 100 y$ r B.P. $)$ deposits at heights of $+17 \mathrm{~m}$ above the present thalweg.

\section{The Gnadalquivir drainage basin}

The Guadalquivir River basin (Fig. 1) is characterized by a very gentle profile in its lower reach. During glacial periods fluvial deposition extended onto the present 


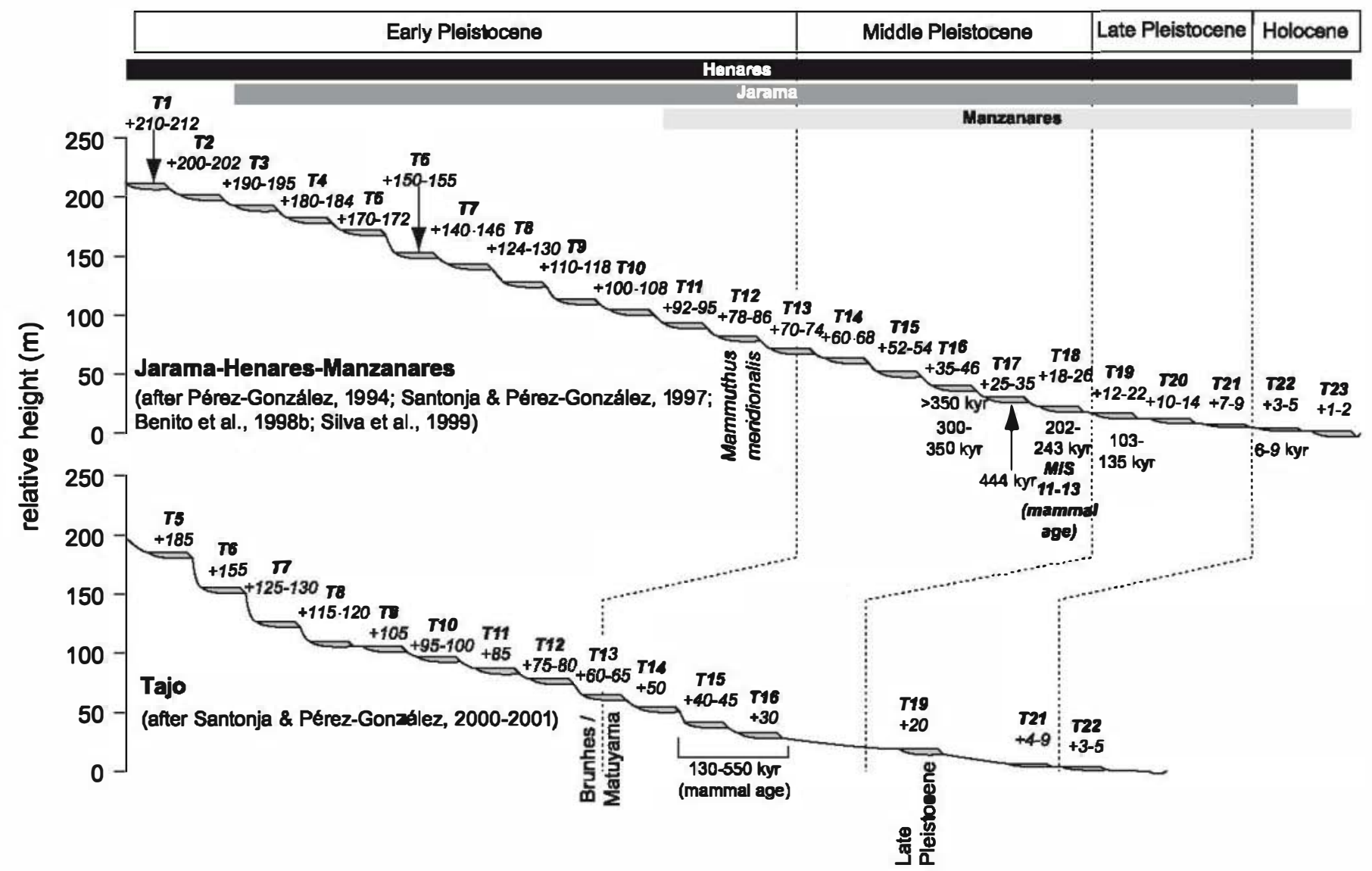

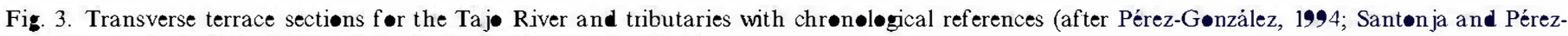
G•nzảlez, 1997, 2000-2001; Benit• et al., 1998b; Silva et al., 1999).

continental shelf, while during interglacials the sea invaded the lower river and coastal marshes developed. Consequently, terrace sequences in the lowermost reach show just Holocene deposits, whereas Middle to Late Pleistocene terrace deposits are below present sea level, as can be seen in the nearby Guadalete and Tinto-Odiel rivers (Dabrio et al., 2000; Mediavilla et al., 2004). However, further inland the sequences are complete (Table 3, Fig. 4).

\subsection{Early Pleistocene}

The starting reference for the present fluvial network must be placed at the 'Raña', a local term referring to high and wide platforms paved with siliciclastic sediments that surround the basin. Baena and Díaz del Olmo (1997) used palaeomagnetism to date the deposits that cover this surface in the Córdoba area (the Raña in Montoro) to 1.757 Ma (Matuyama/Olduvai) (Table 3, Fig. 4). Accepting this age, and the correlation of the T4/T5 boundary with the Matuyama/Brunhes boundary, the Early Pleistocene sequence is composed of four terraces with a height range of about $60 \mathrm{~m}$ (Table 3, Fig. 4). Another chronological reference point is the presence of a normal subchron in the T2 terrace, attributed by Baena and Díaz del Olmo (1994) to the Jaramillo.

\subsection{Middle Pleistocene}

The Middle Pleistocene Late Pleistocene boundary must be placed between T12 ( $80 \mathrm{ka}$ in a soil on the surface of the terrace) and T10 (180ka, Biwa I event) (Baena and Díaz del Olmo, 1994; Table 3; Fig. 4). As a compromise, we have chosen the top of the T11 terrace as the boundary (Table 3, Fig. 4). Accordingly, the Middle Pleistocene sequence comprises seven terraces (T5 to T11) with a total height range of $90100 \mathrm{~m}$. A reversed subchron within the Brunhes chron has been detected by Díaz del Olmo et al. (1993) in the T10 terrace and interpreted by Baena and Díaz del Olmo (1994) as the Biwa I event ( $\approx 180$ ka).

\subsection{Late Pleistocene and Holocene}

The Pleistocene Holocene boundary cannot be defined in the fluvial sequences because from T13 downwards the only available data are archaeological discoveries (Table 3, Fig. 4). These are represented in the lowermost terrace by post-Chalcolithic industries, while $\mathrm{T} 13$ and T14 show middle Palaeolithic industries (Late Pleistocene). Díaz del Olmo and Borja (1991) and García Martínez et al. (1999) defined a sequence from the Holocene comprising terraces dated to $84 \mathrm{ka}$, to Roman times, to the Middle Ages and two 20th century terraces. 


\section{River Aguas}

Since the pioneering work of Völk (1967) on the Neogene geology and Quaternary geomorphic evolution of the Vera basin, there has been a significant number of studies of Quaternary river terrace sequences in the Cenozoic basins of the Internal Zone of the Betic Cordillera in Southeast Spain (Wenzens, 1992; Harvey et al., 1995; Mather and Harvey, 1995; Schulte, 2002a; Schulte et al., 2007; Stokes and Mather, 2003). In this paper we focus predominantly on the sequence of the

Table 3

Terrace sequence for the Guadalquivir River and chrøn॰legical references after Díaz del @m• et al. (1993) and Baena and Díaz del Olm• (1994)

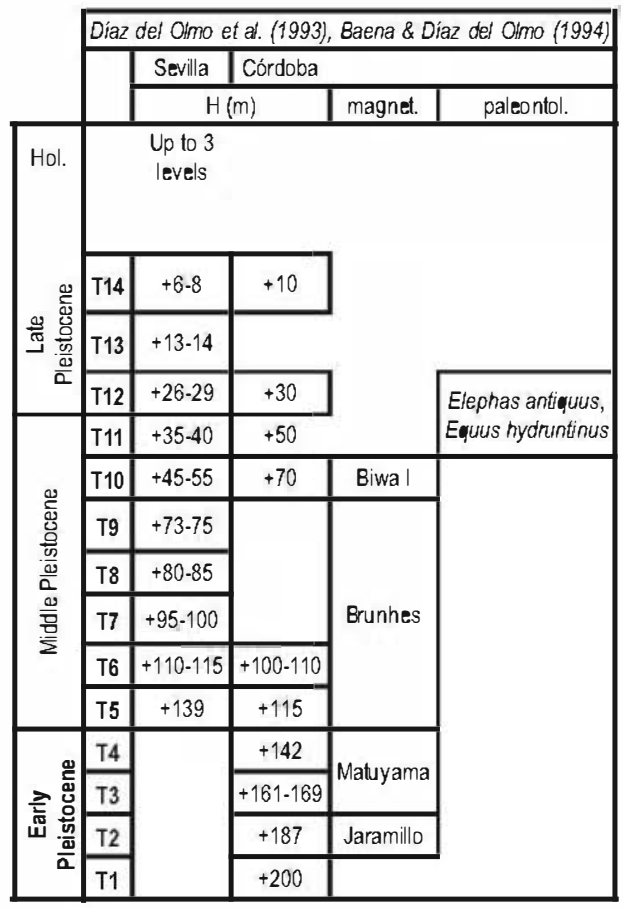

The terrace codes f $\bullet$ llow the authørs' nømenclature.
Aguas, the most complete and best-dated fluvial chronosequence of Southeast Spain, and establish correlation with the terrace sequence of the Antas River.

SE Spain is one of the most active seismic areas of the Iberian Peninsula (Montenat et al., 1990; Braga et al., 2003). As a consequence, long-term fluvial network development has been significantly influenced by tectonics and river capture. As in the Antas and Almanzora catchments (Schulte, 2002a), river captures have produced important changes to the Aguas drainage system, although its chronology is still under debate (Harvey et al., 1995; Kelly et al., 2000; Schulte, 2002a). Schulte (2002a) presented detailed geomorphic mapping of the river terraces from the middle (eastern Sorbas basin) to the lower reach (southern Vera basin) of the River Aguas, providing longitudinal profile data. This chronosequence covers a flight of 19 levels, consisting of pediments, alluvial fans, glacis, fluvial, travertine and marine terraces, that extends from the Pliocene to the present (Table 4, Fig. 5).

\subsection{Pliocene and Early Pleistocene}

The late Neogene uplift of the Betic Cordillera led to the subsequent shift from marine to continental sedimentation environments from the inner to the outer basins of the Betic Internal Zone. Consequently, marine deposition ceased in the Huercal Overa basin at the end of the Messinian, in the Sorbas basin during the lower Pliocene and in the Vera basin during the upper Pliocene (Montenat et al., 1990).

The earliest morphological feature in the lower Aguas catchment (southern Vera basin) that represents continental fluvial conditions is the pediment $\mathrm{P} 1$ at $+101 \mathrm{~m}$ above the valley floor (Fig. 5, Table 4). The chronological control and possible correlation of sloping surfaces eroded in limestone is difficult (Schulte, 2002a), whereas the relative chronological control of the beginning of the fluvial sequences of the Antas catchment and the upper Aguas catchment is defined by the biostratigraphical records of coastal plain sediments. In the central Vera basin the

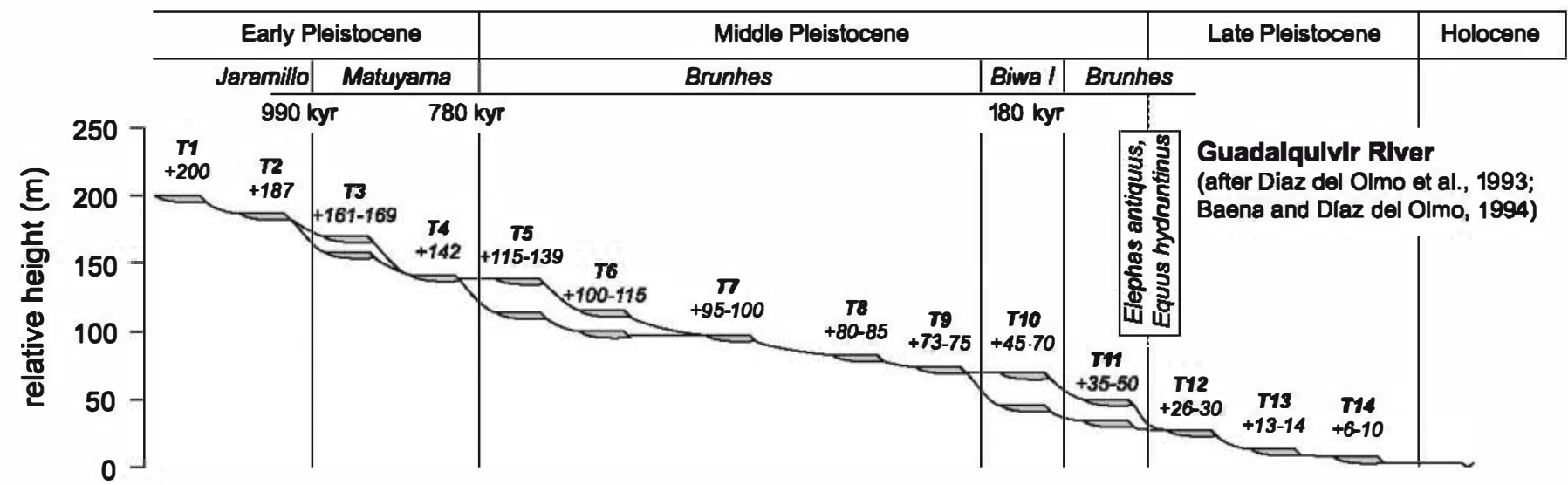

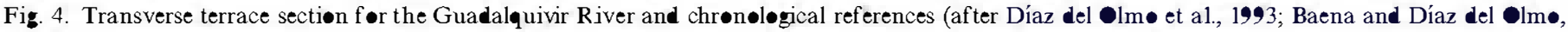
1994). 
Table 4

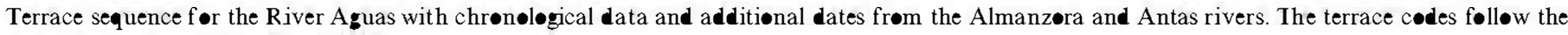
-riginal names from Schulte (2002a)

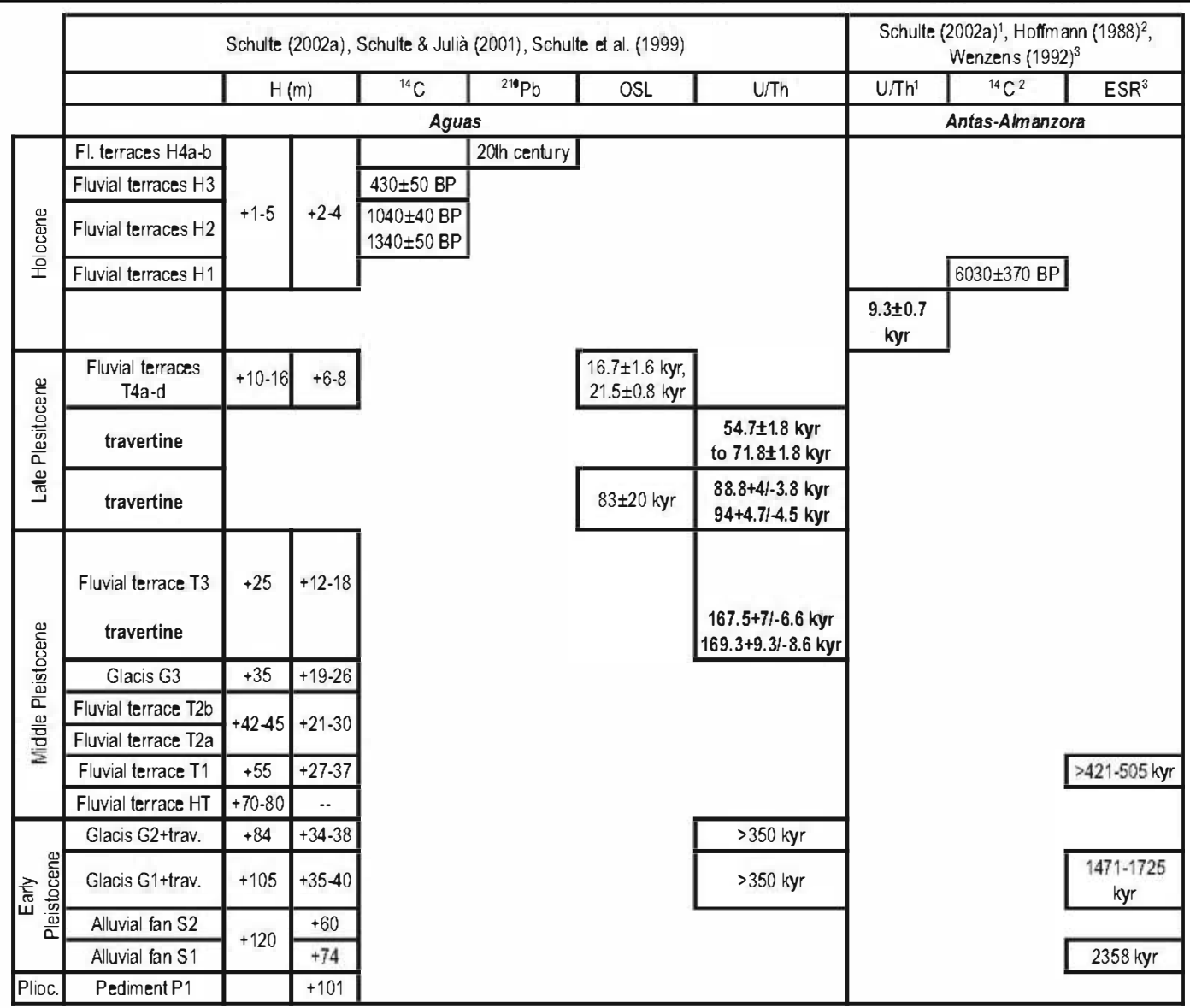

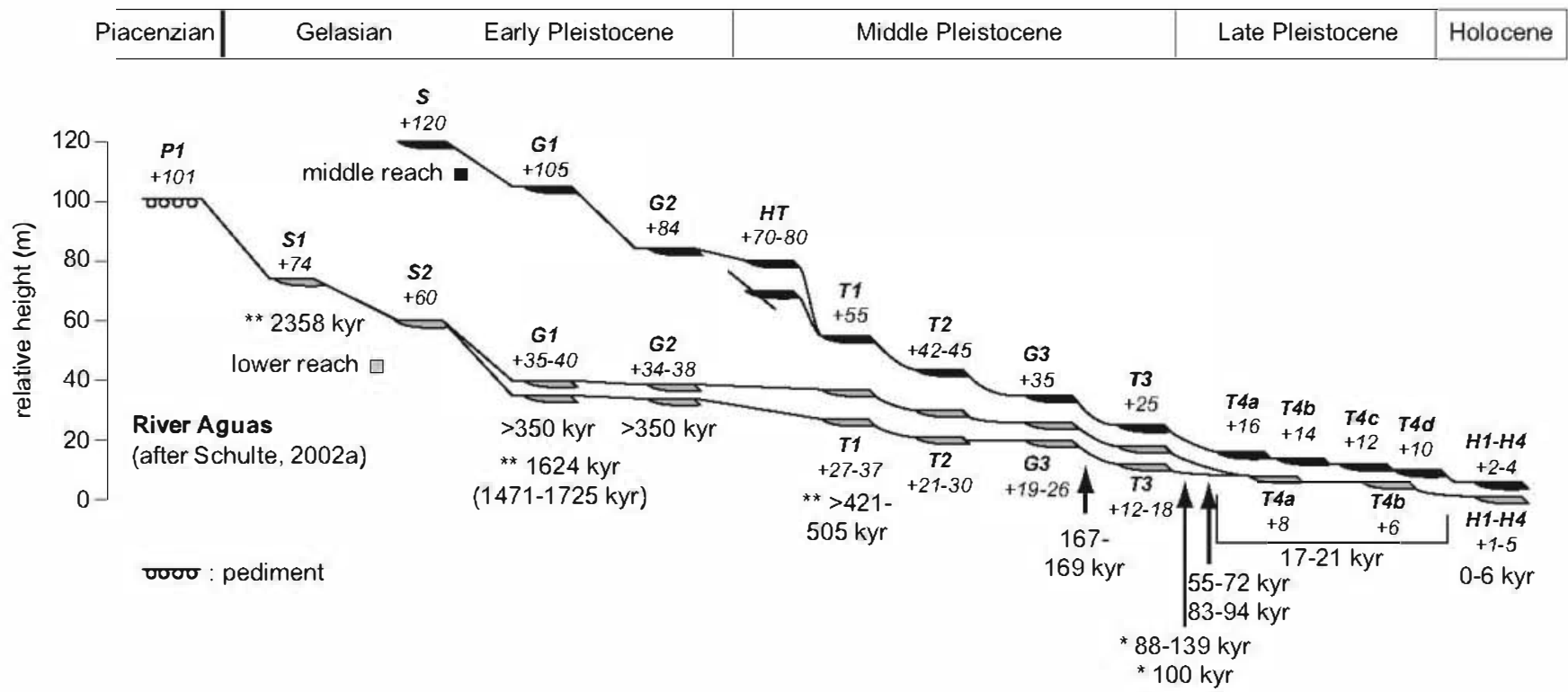

Fig. 5. Transverse terrace section f $\bullet$ the River Aguas and chrønøløgical references (after; Schulte et al., 2000; Schulte and Juliả, 2001, and Schulte,

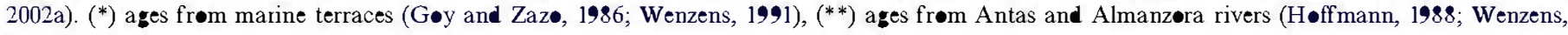
1992). 
alluvial fans (S1), the oldest fluvial deposits of the Antas catchment, overlie the upper Pliocene delta deposits of the Espiritu Santo Formation, whereas in the Sorbas basin the earliest alluvial fan deposits (Moras Member) are interbedded with the lower Pliocene coastal plain deposits of the Zorreras Member (Mather and Harvey, 1995). During the Pliocene, filling of the eastern Sorbas basin passed up into the braid-plain and alluvial fan deposits of the Gochar Formation, whereas uplift during Early Pleistocene led to fluvial incision punctuated by river terrace aggradation. The oldest fluvial terrace is designated by Mather and Harvey (1995) and Harvey et al. (1995) as terrace A and corresponds with terraces S1 and G1 of Schulte's (2002a) Aguas chronology.

The Early Pleistocene Middle Pleistocene boundary is not precisely defined in the Aguas due to the lack of palaeomagnetic records and precise radiometric dating. Schulte and Julià (2001) used pedostratigraphical criteria to establish a river terrace chronosequence in the southern Vera basin and Harvey et al. (1995) applied soil index properties in the eastern Sorbas basin.

The Quaternary soil chronosequence observed on the River Aguas terraces shows an increasing soil development with older terrace age. Schulte and Julià (2001) attributed the well-developed red Mediterranean soils (rhodoxeralfs) on the alluvial fans S1 $(+74 \mathrm{~m})$ and S2 $(+60 \mathrm{~m})$ and on the glacis G1 $(+40 \mathrm{~m})$ and $\mathrm{G} 2(+38 \mathrm{~m})$ to the Early Pleistocene, whereas the less-developed reddish Mediterranean soils (haploxeralfs) are assumed to indicate Middle and Late Pleistocene ages. The formation of rhodoxeralfs can be ascribed to more favourable climatic conditions (seasonally hot/dry and more humid) during the early Pleistocene, as shown by Mediterranean oxygen isotope records (Vergnaud Grazzini et al., 1990) and palaeoecologic studies of a Plio-Pleistocene lacustrine sequence of the nearby Baza basin (Anadón et al., 1994). However, relative pedostratigraphical criteria such as 'redness rating' (Torrent et al., 1980) and development of calcic and petrocalcic horizons show important local and regional variability in southeast Spain and should therefore be interpreted with caution (Schulte and Julià, 2001; Schulte, 2002a).

Several radiometric ages were obtained from fluvial deposits of the Vera basin that were previously assumed to be Early Pleistocene. However, the resultant ages fail to provide a precise chronology. In the case of the U/Th dating of two interfingering travertines in terraces (glacis) G1 and G2 (Schulte, 2002a), the data show minimum ages of $>350 \mathrm{ka}$, whereas ESR dating of interbedded travertines in the Almanzora catchment (2358 ka and $17251471 \mathrm{ka}$ ) represents only crude age estimates (Wenzens, 1992).

During the Early Pleistocene the proto-River Aguas still drained the eastern Sorbas basin to the south, crossing the Sierra Alhamilla-Cabrera, and the fluvial system of the southern Vera basin was controlled by the Jauto River, as indicated by changes in lithology and thickness of river terrace deposits upstream and downstream of the Jauto Aguas confluence (Schulte, 2002a).

\subsection{Middle Pleistocene}

The HT terrace $(+80 \mathrm{~m})$ was formed only in the upper reach of the Aguas (Schulte, 2002a) and represents the last fluvial terrace before river capture of the proto-Aguas by a tributary of the Jauto. Subsequently the Aguas drained to the Vera basin in the east (Harvey et al., 1995). This capture event is marked by the change in the middle reach of the Aguas from a wide valley with gentle slopes to a narrow steeply incised valley.

However, the chronology of the river capture and the subsequent aggradational terraces is a contentious issue, as a result of difficulties in accurate dating and interpretation. Based on the correlation of calcrete development and quantitative soil characteristics expressed by the 'Harden Index' (Harden, 1982) with soil chronosequences of California (McFadden and Hendricks, 1985), Harvey et al. (1995) interpreted the age of the HT terrace (their terrace C) as $>100 \mathrm{ka}$, suggestive of MIS 6 5. Kelly et al. (2000) undertook U-series dating on calcretes in the upper reach of the Aguas, obtaining ages of $91 \pm 11$ and $80 \pm 17$ ka from a massive calcrete developed in the HT terrace. We would argue, however, that determination of the chronology of river terraces by dating calcretes is questionable because of complexities of the polygenetic processes of calcium carbonate mobilization and deposition, as has been reported from many soils in the semi-arid Mediterranean basin (Bronger et al., 1992; Yaalon, 1997; Kelly et al., 2000). Moreover, even accurate dating of these processes provides only minimum ages that can differ greatly from the timing of original terrace aggradation.

In semi-arid southeast Spain, increased intensity of pedogenic processes, groundwater circulation and other factors can result from specific palaeoclimatic conditions. Several ages between 9600 and $8430 \mathrm{yr}$ B.P., obtained by $\mathrm{U} / \mathrm{Th}$ dating of carbonate-cemented horizons and pedogenic calcrete nodules (Candy et al., 2004), by AMS dating of pollen concentrations extracted from the coarse-grained sediments of the lower Aguas terraces (Schulte, 2002b) and by U/Th dating of a travertine in the Antas valley (Schulte, 2002a), could be related to the more humid climatic conditions and the increased vegetation cover during the Early Holocene rather than dating the aggradation of the terraces that were sampled.

In the lower Aguas valley, chronological control of morphological terrace features improves after MIS 6 (Table 5, Fig. 5). The braided river terrace T3 (= terrace D2 of Harvey et al., 1995), located between 12 and $18 \mathrm{~m}$ above the Aguas riverbed, corresponds, according to $\mathrm{U} / \mathrm{Th}$ dating of underlying travertine $(167.5 \pm 6.8 \mathrm{ka}$, $169.3 \pm 8.9$ ka), with MIS 65 (Schulte, 2002a; Schulte et al., 2007).

ERS data of a petrocalcic horizon developed on fluvial terrace G3 of the proto-Antas and Almanzora river, obtained by Wenzens (1991) in the Vera basin near the coastline, provide an age estimate of $650547 \mathrm{ka}$, whereas the Middle Pleistocene Late Pleistocene boundary here is 
better defined by a marine terrace dated 11588 , 139112 and 100 $\pm 6.5 \mathrm{ka}$ (Goy and Zazo, 1986; Wenzens, 1991).

\subsection{Late Pleistocene and Holocene}

In the Aguas and in its south-bank tributary, the Rambla Ancha, the lowest terrace level T4 can be subdivided into four fluvial terraces, located between 15 and $7 \mathrm{~m}$ above the riverbed (Table 4, Fig. 5; Schulte, $2002 \mathrm{~b}$ ). IRSL dates show an age of $21.5 \pm 0.8 \mathrm{ka}$ for the oldest terrace, $T_{\mathrm{I}}$ of the Rambla Ancha, and $16.7 \pm 1.6 \mathrm{ka}$ for the third lowest terrace, $T_{\text {III }}$ (Schulte et al., 2000). However, the late Pleistocene terraces T4a-d of the Aguas post-date the incision that occurred after the final

Table 5

Terrace sequences for the Guadiana basin and chrøn॰løgical references

\begin{tabular}{|c|c|c|c|c|c|c|}
\hline & \multicolumn{2}{|c|}{$\begin{array}{c}\text { Mazo et al., (1990), } \\
\text { Pérez-González (1994) }\end{array}$} & \multicolumn{2}{|c|}{$\begin{array}{c}\text { Rodriguez-Garcia(1998), } \\
\text { Rendelt et al. (1994) }\end{array}$} & $\begin{array}{l}\text { Santonja (1981), } \\
\text { Portero (1988) }\end{array}$ \\
\hline & & \multicolumn{2}{|c|}{ Záncara } & \multicolumn{2}{|c|}{ Guadiana-Gigiiela } & Guadiana \\
\hline & & $H(m)$ & archeol., paleontol. & $H(m)$ & TL, archeol. & $\mathrm{H}(\mathrm{m})$ \\
\hline $\begin{array}{l}\text { Late } \\
\text { Pleistoc. }\end{array}$ & $\mathrm{T} 10$ & $+2-3$ & Mousterian & $+1-2$ & $\begin{array}{c}\text { Mousterian } \\
121.3 \pm 14.2 \mathrm{kyr}\end{array}$ & $+2 \cdot 3$ \\
\hline \multirow{3}{*}{ 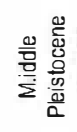 } & $\mathrm{Tg}$ & \multirow[t]{3}{*}{$+6-8$} & & \multirow[t]{3}{*}{$+6-9$} & & $+6-7$ \\
\hline & T8 & & & & & $+8-9$ \\
\hline & $\mathrm{T7}$ & & & & & $+10-12$ \\
\hline \multirow{6}{*}{ 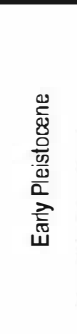 } & T6 & $+15-16$ & $\begin{array}{l}\text { Mammuthus } \\
\text { meridionalis, } \\
\text { Bovidae ind. (Bos } \\
\text { or Bison) }\end{array}$ & $+13-14$ & & $+13-16$ \\
\hline & T5 & \multirow{5}{*}{\multicolumn{2}{|c|}{$+30-35$}} & & & $+18-20$ \\
\hline & $\mathrm{T} 4$ & & & & & $+28-30$ \\
\hline & $\mathrm{T} 3$ & & & & & $+35-37$ \\
\hline & $\mathrm{T} 2$ & & & & & $+42-44$ \\
\hline & $\overline{T 1}$ & & & & & $+60-65$ \\
\hline
\end{tabular}

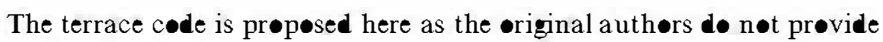
terrace numbering. travertine aggradation, at around $54.7 \pm 1.7 \mathrm{ka}$ (Schulte, 2002a).

The Holocene is represented by four terraces, formed, except for the highest one, during historical times. The H1 terrace predates the Chalcolithic period $(49504200$ cal. yr B.P.), whereas the younger terraces show dates from the 10th century onwards: (961 $1034 \mathrm{cal}$. yr A.D. for terrace H2, 1417 to 1611 cal. yr A.D. for terrace H3 and the end of the 1940s (20th century) for terrace H4; Schulte, 2002b).

\section{The Guadiaua basiu}

In the Guadiana River basin (Fig. 1) the very low downstream gradients, in conjunction with subsidence, favoured prolonged aggradation of Neogene fluviolacustrine deposits until 1.9 1.5 Ma, as showed by faunas found in these deposits (Mazo et al., 1990; Mazo, 1999). The first dated terrace levels correspond to the Fuensanta $(+60 \mathrm{~m}$, Júcar River) and El Provencio (+15 $16 \mathrm{~m}$, Záncara River) fossil sites (Table 5, Fig. 6). Faunas from these sites provide an age of around $1 \mathrm{Ma}$. In addition, the $+12 \mathrm{~m}$ terraces of the Záncara and Guadiana rivers have been dated as $121.3 \pm 14.2 \mathrm{ka}$ by luminiscence (Rendell et al., 1994). The resulting terrace sequence is composed of six Early Pleistocene terraces, three Middle Pleistocene terraces and one Late Pleistocene terrace, although the Early/Middle Pleistocene boundary is not precisely defined.

Important deposits are those in the Las Tablas de Daimiel, a fluvial wetland at the junction of the Guadiana and Gigiiela Rivers. These deposits form a stack of fluvial and palustrine/lacustrine sediments that extend from MIS 10 to the present day (Valdeolmillos, 2005).

\section{The Duero basiu}

The Duero has the largest drainage basin in Spain (Fig. 1), which is also the highest of the great basins. The fluvial sequences of this basin have been studied from the outset of such research but, curiously, there are no absolute

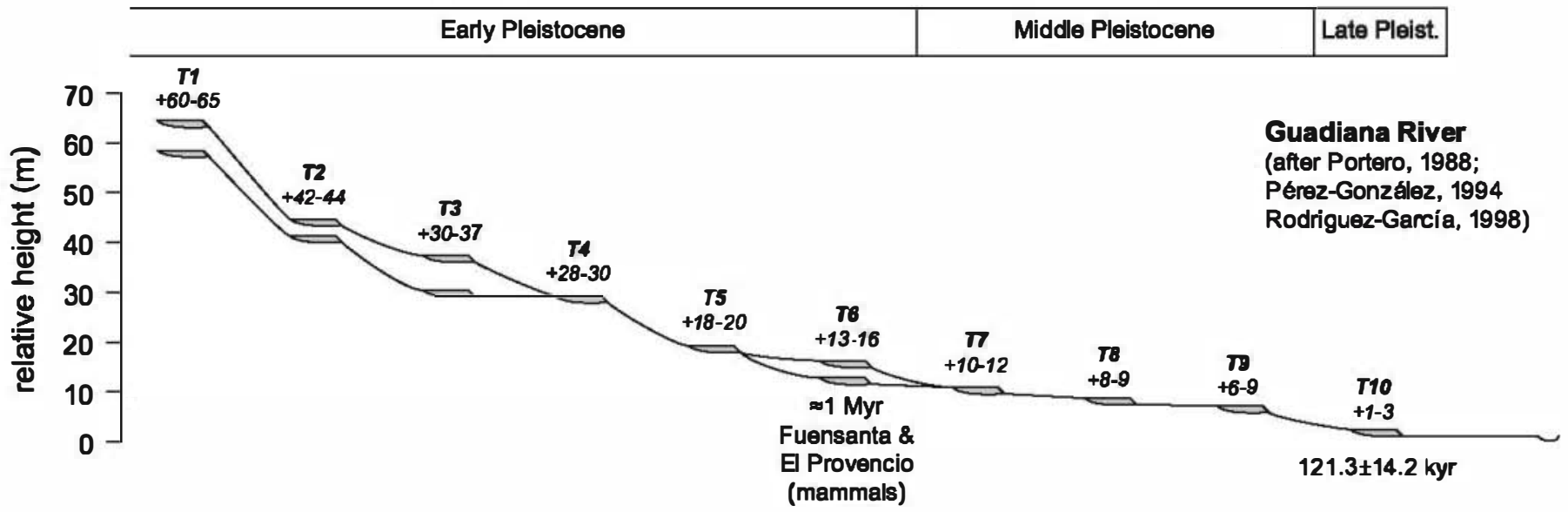

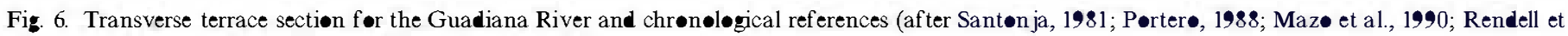
al., 1994; Pérez-Gønzảlez, 1994; Rødíguez García, 1998). 
ages for their deposits and, due to the scarcity and quality of fossil sites, there are too few palaeontological remains to provide a precise chronology for these sequences. On the other hand, the relative abundance of archaeological sites has led many authors to correlate the terrace sequences on the basis of topographical position and cultural sequence (Table 6; Fig. 7).

The only palaeontological references found in the basin are the Tariego de Cerrato fossil site (in the $+165 \mathrm{~m}$ terrace of the Pisuerga River), which yielded mammal fossils belonging to the upper Turolian (upper Miocene) in the first incised deposits found in that area (Santisteban et al., 1997; Mediavilla, 2001), and the presence of elephant, probably Elephas (Palacoloxodon) antiquus, Equas, and Bes in the $+30 \mathrm{~m}$ terrace of the Pisuerga near Valladolid (Santonja and Pérez-González, 1984), which places this terrace in the Middle Pleistocene.

According to the classical correlation of terraces and relative chronologies (Santonja and Pérez-González, 1984, 1997), the Early Pleistocene sequence is composed of six, the Middle Pleistocene of eight and the Late Pleistocene of

Table 6

Terrace sequences f $\bullet$ the Duer $\bullet$ River and tributaries

\begin{tabular}{|c|c|c|c|c|c|}
\hline & & & \multicolumn{3}{|c|}{$\begin{array}{l}\text { Santonja \& Pérez-González (1984), } \\
\text { Santonja \& Pérez-González (1997) }\end{array}$} \\
\hline & & & Duero & $\begin{array}{c}\text { Tormes and } \\
\text { W Salamanca }\end{array}$ & Pisuerga \\
\hline & & & $H(m)$ & $H(m)$ & $H(m)$ \\
\hline Hol. & & $T 21$ & $+3-5$ & $+3-5$ & +5 \\
\hline \multirow{4}{*}{$\begin{array}{l}\frac{\dot{m}}{\omega} \\
\frac{\dot{\omega}}{\alpha} \\
\dot{-}\end{array}$} & M.Paleol. & $T 20$ & & & \\
\hline & \multirow{3}{*}{$\begin{array}{l}\dot{\bar{\Xi}} \\
\frac{\mathrm{J}}{\mathrm{U}} \\
\dot{\mathrm{U}} \\
\dot{3}\end{array}$} & T19 & & $+6.8^{\circ}$ & +10 \\
\hline & & T18 & +8.12 & $\cdot$ & \\
\hline & & $T 17$ & & $+12.14^{\circ}$ & \\
\hline \multirow{8}{*}{ 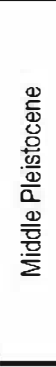 } & \multirow{5}{*}{ 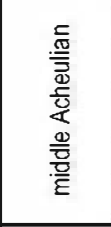 } & T16 & +18.22 & +18.20 & +20 \\
\hline & & T15 & $+24.30^{\circ}$ & $(+22.24)^{\circ}$ & \\
\hline & & T14 & \multirow[t]{2}{*}{ ?? } & $+34^{\circ}$ & $+30^{1}$ \\
\hline & & $T 13$ & & $(+35.40)^{\circ}$ & \\
\hline & & T12 & +40.48 & +42.44 & \\
\hline & \multirow{5}{*}{ 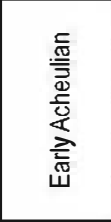 } & T11 & $+54-56$ & $+50.54^{*}$ & +40 \\
\hline & & $T 10$ & +62 & $+62.64^{\circ}$ & \\
\hline & & T9 & $+74.80^{\circ}$ & $+78-80$ & \\
\hline \multirow{7}{*}{ 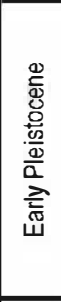 } & & $\mathrm{T} 8$ & +82.84 & & \\
\hline & & $T 7$ & $+96-100$ & & \\
\hline & \multirow{5}{*}{ 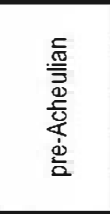 } & T6 & $+102 \cdot 107$ & $(+100)^{*}$ & +60 \\
\hline & & $T 5$ & $+110-114$ & & +80 \\
\hline & & $\mathrm{T} 4$ & $+126-134$ & +108 & +120 \\
\hline & & T3 & $+141-144$ & & \\
\hline & & $\mathrm{T} 2$ & & +120 & \\
\hline & $\begin{array}{l}\text { eogene } \\
\text { Turolian) }\end{array}$ & T1 & & & $(+165)^{1}$ \\
\hline
\end{tabular}

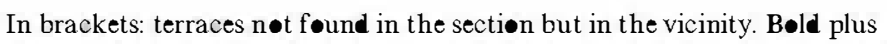
underlined: sites with archaeological findings. $\left.{ }^{*}\right)$ : archae logical sites. (1): mammal sites. five terraces (Fig. 7; Table 6), while the lowermost terrace is ascribed to the Holocene on the basis of regional criteria.

\section{Discussion}

Spanish Quaternary fluvial terrace sequences have developed in a very wide range of topographical and morphological conditions, under differing influences of climate, tectonics and relation to sea level. However, key to an understanding of these fluvial sequences is time control. In fact, the dating control of these sequences is very variable, due to (1) the characteristics of the dated materials and (2) limitations of accuracy and range of dating methods.

As a consequence of these factors, the stratigraphy of different terrace sequences varies in relation to chronological and spatial resolution. These aggradational terraces are composed of coarse-grained siliciclastic sediments that, due to hydrodynamic and diagenetic processes, are generally unsuitable for the preservation of organic remains (bones, shells, etc.), thus precluding biostratigraphy as a means for dating (with notable exceptions such as the Tajo sequence). The accuracy of radiometric dating techniques applied in fluvial environments varies according to the presence of datable material, dating range, care in sample selection, stratigraphical context, purity and diagenetic contamination. In our opinion, radiocarbon assay of organic material and U-series dating of travertine are the most reliable standard dating methods to have been applied to Spanish fluvial sequences. Effective time range is one of the major constraints. The boundary of U-series dating limits its utility to $350 \mathrm{ka}$ (around MIS 11). OSL dating and aminochronology are experimental techniques that remain of equivocal accuracy.

The final group of methods used are the 'relative' and 'sequential' ones, in which we can include palaeomagnetism, palaeontological (biostratigraphy), cultural (archaeological) and pedostratigraphical sequences. All of these share the same feature: they provide only a succession of events so, in order to use them as chronological references, they need absolute dates to place them in the chronological scale. In addition, there are assumptions in such methods that must be clearly stated to validate their results. The most important is the global validity, or otherwise, of the observed changes, some of which might be of only local influence and, therefore, of no value for correlation purposes over large distances. In particular, such changes might be diachronous and, as a consequence, provide only a broad guide of age rather than a precise date.

As a consequence of all these factors, the present discussion will be conditioned by the very inhomogeneous availability of dates (see Fig. 8). We shall try to show the main common features of these sequences in an attempt at reconciliation of the existing chronological points of reference. When the available data allow it, we shall relate those records with the global Quaternary climatic (MIS) record. 


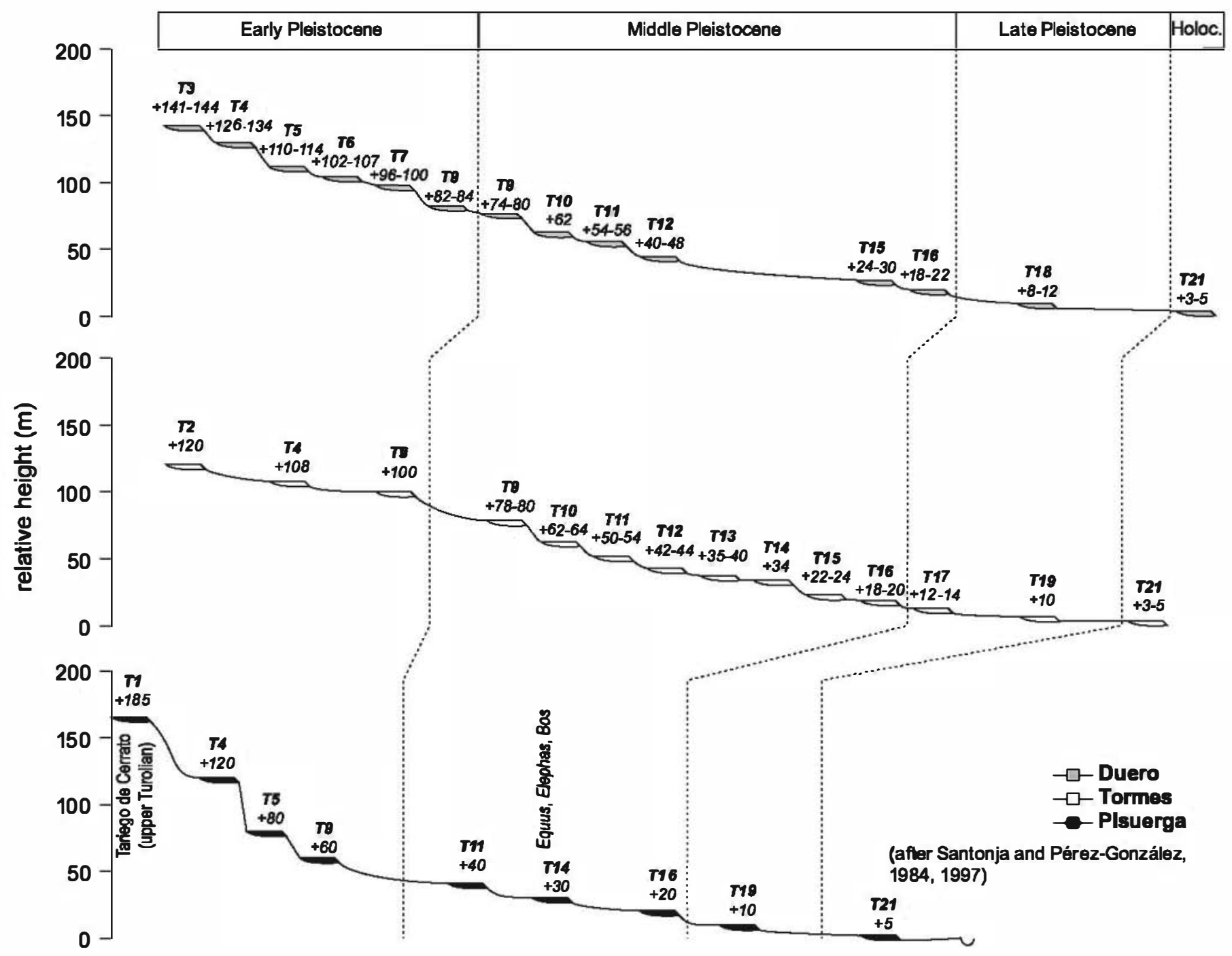

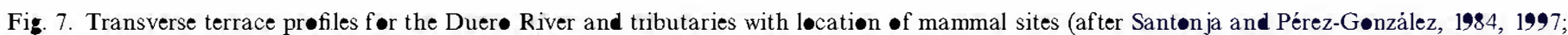
Santisteban et al., 1997).

\section{1. 'When did incision begin?'}

The Early Pleistocene and older terraces have fewer dates or chronological reference points, but there is an interesting question arising from the published records, which is 'how old is the beginning of incision in Spain?' or, in other words, when did terrace sequences start to form? The data from the sequences presented in this paper provide some clues.

In the Vera basin, the end of basin filling followed deposition of the biostratigraphically dated upper Pliocene deltaic sediments. However, fluvial systems developed earlier in the inner basins of the Betic System, as is indicated by the positions of Miocene shorelines. In the case of the Aguas and Antas river catchments, the first fluvial processes are documented by pediments and alluvial fans located next to the surrounding ranges, whereas the first fluvial system is represented by the remnants of the G1 level.

A Piacenzian/Gelasian age is assigned to the uppermost deposits in the Tajo basin, as a reverse/normal magnetic transition here is attributed to the Matuyama/Gauss boundary (Torres et al., 1994b). In this case, however, the lack of geochronology makes this somewhat hypothetical, as there are no criteria from which an Olduvai origin for this change can be eliminated.

Palaeontological criteria provide ages of around 1.9 1.5 Ma (Mazo, 1999) for the end of the Guadiana basin infilling, around the Olduvai subchron. A similar age is assigned, on the basis of palaeomagnetic criteria, to the Raña de Montoro (Baena and Díaz del Olmo, 1997), the starting point of terrace incision by the Guadalquivir system.

Independent of the error margins of these ages, what remains is that the start of fluvial incision in Spain was diachronous between the various systems.

\subsection{The Early Pleistocene and older fluvial record in the Iberian Peninsula: a question of antiquity}

Independent of the starting point of fluvial incision, the Early Pleistocene and older fluvial sequences in Spain are 


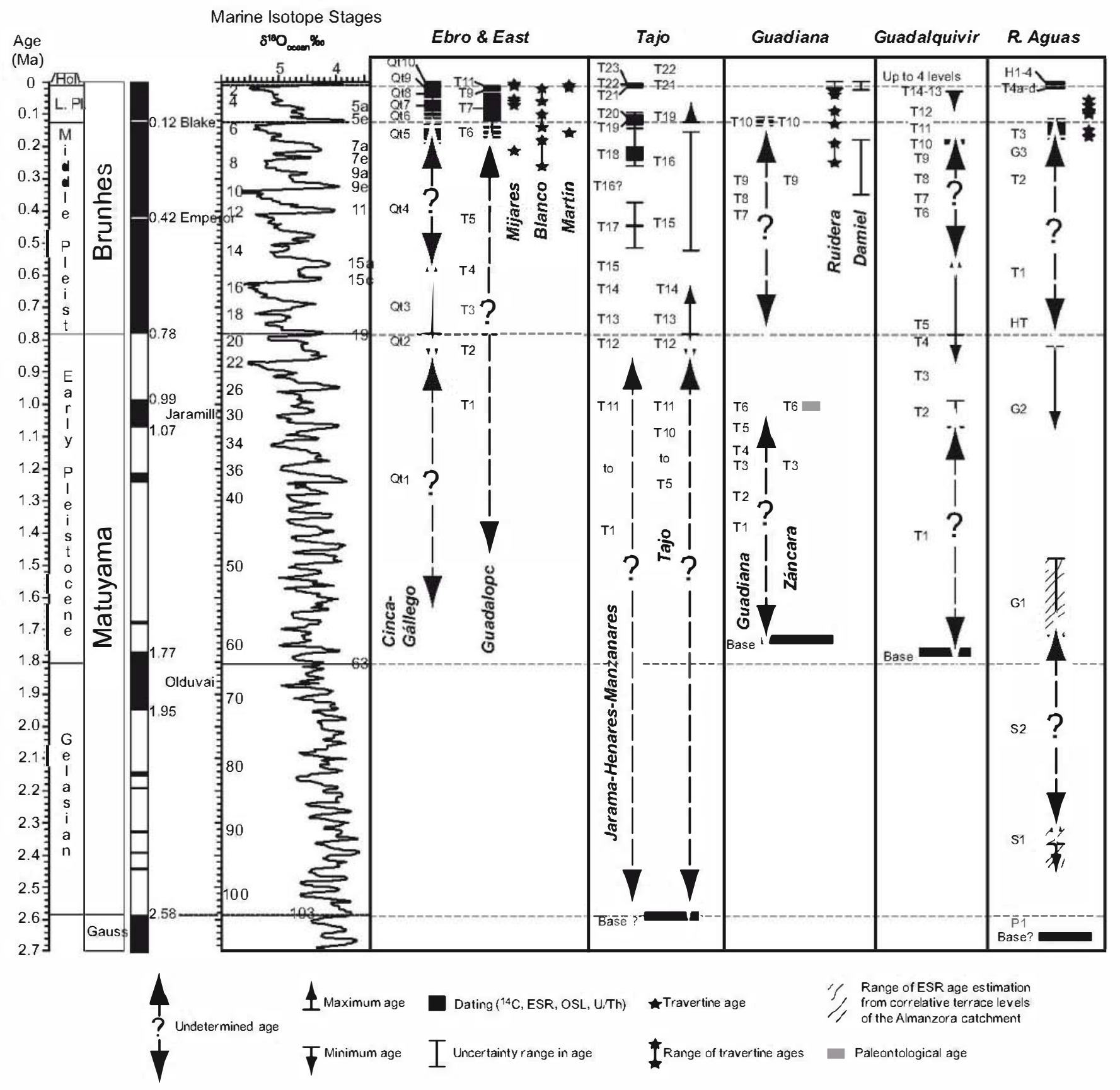

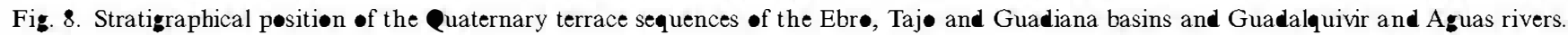

well bounded, as the Early/Middle Pleistocene boundary can be precisely located in almost all the basins reviewed here (Fig. 8).

Palaeomagnetic criteria allow this boundary to be defined in the Ebro, Tajo and Guadalquivir basins. In the Vera and Sorbas basins the boundary is derived from pedostratigraphical data, whereas in the Guadiana basin a combination of palaeontological (T6 terrace around 1 Ma) and archaeological (a Middle Pleistocene age is assumed for the T7 terrace on the basis of the presence of Acheulian artefacts) criteria is used. Another chronological reference point indicative of an Early Pleistocene age is the identification of the Jaramillo subchron in the Guadalquivir basin.

Taking into consideration the poorly dated and clearly diachronous start of incision, the Early Pleistocene and older sequence in Spain are composed of a variable number of terraces that, in the absence of dates, are difficult to correlate with one another or with global events such as the marine Oxygen Isotope Stages.

Despite this, there are some facts worthy of mention. Near-coastal sequences and those with profiles minimally above sea level have lower numbers of Early Pleistocene terraces: The Aguas has four (Fig. 5, Table 4) and the 
Guadalquivir four (Fig. 4, Table 3), whereas further inland a greater number of terraces is preserved; the Guadiana has six (Fig. 6, Table 5), the Duero six (Fig. 7, Table 6) and the Tajo twelve (Fig. 3, Table 2).

This pattern may relate to the response of channel adjustment to rapid Quaternary eustatic sea-level changes of a range up to $130 \mathrm{~m}$ in the coastal drainage networks, as demonstrated in the Aguas catchment by Schulte et al. (2007), and the moderate upstream effect of baselevel changes to the upper reaches of larger rivers (Schumm, 1993).

Furthermore, enhanced erosive capabilities also occur in upper river catchments, e.g. the Cinca and Gallego, where headwater fluvial dynamics are controlled by climate (shifting glacial and periglacial environments in the Pyrenees during glacial/interglacial periods) and increased tectonic uplift rates (McDonald et al., 2003; Jones et al., 1999).

The Jaramillo magnetic event might be usable as a regional marker, although with low confidence in its definition, as there are criteria to identify this period in the Guadalquivir and Guadiana basins. In the Tajo basin this level can only be defined if we assume that the presence of Mammuthus meriodionalis and pre-Acheulian artefacts in the terraces can be used as a correlation tool. But there are no criteria to assess its presence or absence in the Ebro or SE basins.

\subsection{Middle Pleistocene}

Chronological reference points increase towards the end of the Middle Pleistocene, as the first widely identified palaeomagnetic boundary is the Matuyama/Brunhes; more palaeomagnetic data are available and more OSL and Th/ $\mathrm{U}$ dates have been measured from more recent contexts (Fig. 8).

Magnetostratigraphy and pedostratigraphical data, plus an aminochronology date available for the TrabequeEscabas-Guadiela (733 ka: Torres et al., 1994a), allow the first regional level to be placed approximately at the base of the Middle Pleistocene, which corresponds to the T13 terrace of the Tajo River, in which Pinilla et al. (1995) were able to identify the Matuyama/Brunhes boundary. Furthermore, the pedostratigraphical data from Aguas T1 and Antas G3, in SE-Spain, point to a Middle Pleistocene age for subsequent levels. Tentatively, the T7 level of the Guadiana River can be assigned to the earliest Middle Pleistocene. In the Ebro basin there are no criteria to apply in the Guadalope system, in which one of the five terrace levels below T6 perhaps corresponds with this age. In the Cinca and Gállego rivers the Qt3 terrace, with the first record of the Brunhes chron, is the equivalent point in the sequence.

Except for the Tajo basin, where mammal data and travertine dates provide ages from 550 to $202 \mathrm{ka}$, there are no chronological reference points earlier than $\sim 180 \mathrm{ka}$, in the youngest Middle Pleistocene terraces. In the case of the Guadiana basin, there are no Middle Pleistocene dates.

The youngest Middle Pleistocene ages recorded in terrace sequences are from Aguas T3, from Ebro basin T6 and Qt5, which span 180 to around $100 \mathrm{ka}$, and from T11 of the Guadalquivir, which is younger than $180 \mathrm{ka}$ (post-Biwa I event). In the Tajo basin, Middle Pleistocene sedimentation finished with the T18 terrace, which is $243202 \mathrm{ka}$ in age.

Thus, the Middle Pleistocene terrace sequence is represented by five to six terrace levels in the Aguas, Guadalquivir and Tajo systems, probably related to the influence of orbital forcing of climate cycles. However, the Ebro and Guadiana basins have only three Middle Pleistocene terraces. The difference in number of terraces can perhaps be related to differentiatial tectonics, documented by river captures and diversions, different uplift rates as well as to varying degrees of terrace preservation.

\subsection{Late Pleistocene and Holocene}

From the Middle Pleistocene Late Pleistocene boundary onwards, the record is more complete but results from the different basins vary considerably (Fig. 8). The sequences of the rivers Cinca and Gállego, in the Ebro basin, show the most detailed Late Quaternary record, due to a stronger influence of climate on the river dynamics by way of Pleistocene glacier and snow melt. However, the early Late Pleistocene is well recognized in all the basins, both in fluvial siliciclastic sediments and in travertine sequences. From this point onwards there are dated records only in the Aguas and Guadiana systems (travertines) and in the Ebro basin. The end of the Late Pleistocene is recognized in all the basins except the Guadiana, where it is found only in the infilling sequences of the Ruidera and Daimiel.

Upper Late Pleistocene Holocene terraces have been identified in the Aguas (Schulte, 2002b), Tajo (Benito et al., 2003) and Ebro (Andres et al., 2002). Possibly they exist in the other basins but have not been identified or studied. The Holocene is, evidently, present everywhere but detailed studies are only available in the Ebro and the Aguas valley, where at least four levels have been identified, ranging from $>5$ ka to present. Schulte (2003) published a chronostratigraphy of fluvial and alluvial processes of the last 1600 years for the Mediterranean Iberian Peninsula. He showed the importance of climate change on the timing of Holocene aggradation processes that occurred during the Early Medieval Ice Advance and the Little Ice Age.

\subsection{The Iberian Peninsula fluvial sequences in the global record}

Most of the international research on the relation between climate and terrace development has been focused on Middle Pleistocene to Holocene, probably due to the scarcity of dates and sites available for earlier periods. 
Nevertheless, there are some published records of terrace sequences covering the whole Quaternary (Woldstedt, 1958; Bibus 1980; Rose et al., 2001; Tyráček, 2001; van den Berg and van Hoof, 2001; Maddy et al., 2001, 2005) or equivalent infill sequences (Nador et al., 2003).

One of the earliest and best documented terrace flights in central Europe is the sequence in the Rhine (Woldstedt, 1958; Bibus, 1980) and, in particular, in the Middle Rhine, where loess palaeosol stratigraphy, luminescence dating, palaeomagnetism, tephrostratigraphy and potassium-argon dating have been carried out (Schirmer, 1990). Bibus (1980) distinguished between three Pliocene and twelve Pleistocene fluvial terraces and observed that the Early Pleistocene terraces show a wide valley topography, whereas the Middle Pleistocene units are represented by narrow terraces. Tyráček (2001) presented a record from the Bohemian massif, characterized by a high number of terraces for the Early Pleistocene and earlier period (3 Gelasian and 9 Early Pleistocene), while the Middle and Late Pleistocene plus the Holocene are represented by 14 terraces in total. He explains the change from the 'widevalley' Gelasian-Early Pleistocene terraces to the incised 'narrow-valley' Middle Pleistocene to Holocene terraces as due to the change from low-amplitude to high-amplitude climatic cycles. Schaller et al. (2004) calculate, based on the cosmogenically dated terrace sequence of the River Meuse catchment, palaeoerosion rates of $2530 \mathrm{~mm} / \mathrm{kyr}$ for the period from 1.3 to $0.7 \mathrm{Myr}$ and $80 \mathrm{~mm} / \mathrm{yr}$ for the period after $0.7 \mathrm{Myr}$. They attribute this significant increase of erosion not only to changes of climatic but also to tectonic boundary conditions.

In the Iberian Peninsula this change from the 'widevalley' to the incised 'narrow-valley' terraces is recorded only in some river systems. The Aguas, Antas (Schulte, 2002a) and Almanzora (Wenzens, 1992) river systems in southeast Spain show extensive Early Pleistocene glacis and terraces, whereas the Middle Pleistocene to Holocene terraces are mostly confined to narrow terrace remnants. The increase of incision is mainly a consequence of equilibrium adoption of the channel profile and results from tectonically controlled river piracy (Schulte, 2002a). However, the frequency of terrace aggradation and channel incision is triggered by the increased amplitude of climate variability and sea-level changes (Schulte et al., 2007).

The morphological record from the Pyrenees differs from this model. In the upper Cinca valley, phases of terrace aggradation are attributed to pronounced glacial outwash and upstream terrace level divergence to posttectonic erosional denudation and isostatic rebound of the Pyrenees (McDonald et al., 2003). This outstanding Late Pleistocene incision of the Cinca system is also reported to a limited degree from the Gallego catchment. In the lower reach of the River Gallego, channel response is influenced by solution-induced subsidence (Benito et al., 1998).

The Quaternary incision aggradation cycles of the sequences of the Jarama, Henares and Manzanares rivers show little variance of incision rates (Pérez-González,
1994). Furthermore, no narrowing of the Middle or Late Pleistocene terrace can be observed, where downcutting and terrace aggradation shift laterally. The outstanding preservation of the most complete terrace sequences of the Iberian Peninsula (23 terraces) and the number of Middle and Late Pleistocene terraces (8 mayor terrace levels) suggest that river response to climate is controlled by eccentricity ( $\sim 100$ ka cycles) such as observed by the Meuse terrace sequence (Veldkamp and van den Berg, 1993). Regarding the Early Pleistocene river history of the Jarama-Henares-Manzanares system, at the present stage of chronological control it is not possible to attribute Early Pleistocene terraces to specific orbital cycles e.g. the $\sim 41$ ka cycles, as reported by Maddy et al. (2005) from the Gediz river terrace sequence in western Turkey.

In conclusion, the Iberian records reviewed in this paper reveal considerable complexity (Fig. 8). A highly variable number of terraces for the Early Pleistocene and older records would seem to indicate that the response to climatic variations during this period was controlled by local factors. For example, the rivers of the Tajo and Guadiana basins were perhaps conditioned by pre-existing Alpine faults, acting as lines of weakness and bringing about areas of preferential incision, thus promoting the development of high numbers of terraces along such lines. On the opposite side, the very active sierra fronts in the Betic system in south-eastern Spain may have promoted the development of alluvial fans (a positive accumulation form) and glacis. When the high-amplitude (100 ka) climatic cycles began, at the 'Mid-Pleistocene revolution', coinciding with the emergence of the large parts of the basins and with changing, unstable sea-levels, significant fluvial incision occurred and deep fluvial valleys formed for the first time.

As for climatic control on aggradation, chronological data do not allow inferences to be made from the Iberian evidence before the late Middle Pleistocene, when there is no preferential period of terrace formation and we can find both glacial and interglacial terraces, depending on the basin.

Peña et al. (2004a) related their terrace sequence to Pyrenean glacial advances and concluded that the MIS 2 glacial episode (LGM) was not recorded in their study area but that MIS 4 the most important glacial episode. However, in the SE basins this period is not recorded to the same extent and Schulte (2002b) reported that during MIS 2 there was important incision in the lowermost Aguas and Antas and near the coastline of the Vera basin, with the development of braided terraces similar to those of MIS 6 5. In this respect, it is worth mentioning that, for this period only, the Ebro basin shows a complete sequence, whereas in the other basins (Tajo, etc.) MIS 4 and 3 are not recorded.

A last point should not be underestimated. The apparent asynchronous evolution of terrace formation in different fluvial systems results partly from methodological problems and the interpretation of an increased number of 
'absolute' dates. On the one hand these dates allow the attribution of fluvial deposits to specific climatic periods; on the other hand the precision of experimental dating methods is sometimes overestimated and, in the case of single dates, may result in erroneous conclusions. Therefore, with respect to the scope of, for example, luminescence dating, we need broader data sets for the future, with checks available with reference to the applications of other radiometric methods (multi-proxy approach).

\section{Conclusions}

Through time, there are changes in the Iberian fluvial sequences (number of terraces for a period, possible simultaneous episodes, etc.) that seem to point to global constraints acting on these records (climate, glacio-eustasy, geodynamics). In space, variability in number of terraces and spatial patterns give rise to hypotheses about the local setting of each basin (tectonic regime, distance to sea and resulting noticeable influence of sea level changes, influence by glacier oscillations, etc.).

For the Early Pleistocene and older sequences, it seems that the location in relation to the coastline played an important role, as those sequences located inland preserve higher numbers of terraces than those located near sea level. Nevertheless, the independent variables climate and tectonics play their own role and the topographical difference resulting from heights of inland and 'coastal' sections. The influence of sea-level changes, particularly where the shelf is narrow, on river profiles and their amplitudes should be taken into account.

For Middle Pleistocene times, some authors argue that there were noticeable tectonic changes in the basins and this could have caused differences in the number and topographical distribution of terraces among basins. On the other hand the higher amplitude of the climate shifts may have caused more clear-cut triggering of accumulation and erosion processes. Better time control will improve the stratigraphical positioning of such events and the discrimination of those related to local basin effects and those related to geodynamic behaviour of Iberia during this time.

Late Pleistocene to Holocene sequences show differences between basins, but this could also be the result of the increased density of records through better preservation and the availability of dates.

The main future challenges are (a) to get a better chronological control of the sequences by increasing the number of geochronological data sets, (b) focusing on specific boundaries and time windows and (c) the use of multi-proxy approaches in the study of fluvial archives. Precise geochronological control on the timing of changes related to local and regional factors will provide a better knowledge of global climate controls on Iberian river systems and, therefore, a better wide-range comparison of sequences that, in the present state of knowledge, can only be sketched.

\section{Acknowledgements}

The authors would like to thank very warmly David Bridgland (University of Durham) for his patience, council and enthusiasm with the idea of this publication. We are also indebted to Rosario Ojeda for recovering most of the oldest references. We are really grateful to the comments of Jeroen Schoorl and an anonymous reviewer that have improved substantially the clarity of the manuscript. This paper is a contribution to both IGCP 449 and 518 and to the FLAG Focus 1 database.

\section{References}

Anadón, P., Utrilla, R., Juliả, R., 1994. Palaeøenvirønmental recønstructiøn of a Pleistecene lacustrine sequence from faunal assemblages and -stracode shell geøchemestry, Baza Basin, SE Spain. Palaeøgeøgraphy,

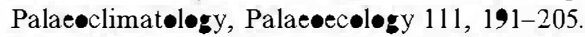

Andres, W., Ries, J., Seeger, M., 2002. Pre-Helecene sediments in the Barranc de las Lenas, Central Ebr Basin, Spain, as indicaters for climate-induced fluvial activities. Quaternary International 93-94, 65-72.

Baena, R., Díaz del Olm•, F., 1994. Cuaternariø aluvial de la depresión

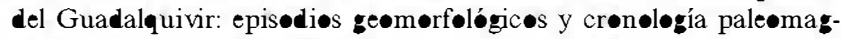
nética. Geøgaceta 15, 102-104.

Baena, R., Díaz del Olm•, F., 1997. Resultades pale»magnetices de la

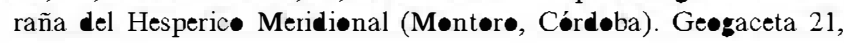
31-34.

Benit•, G., Pérez-Gønzález, A., Gutiérrez, F., Machade, M.J., 1998 a. River response to Quaternary subsidence due to evaporite sølution

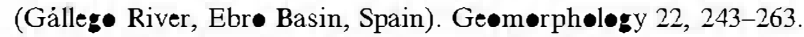

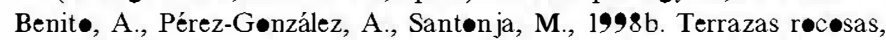
aluviales y travertínicas del valle alt del rí Henares (Guadala jara, España). Geøgaceta 24, 55-58.

Benit•, G., Søpeña, A., Sảnchez-Møya, Y., Machad•, M.J., Pérez-

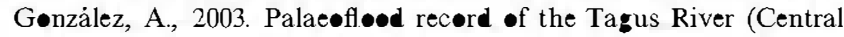
Spain) during the Late Pleistecene and Helecene. Quaternary Science Reviews 22, 1737-1756.

Bibus, E., 1980. Zur Relief-, Beden- und Sedimententwicklung am unteren Mittelrhein. Frankfurter gewissenschaftliche Arbeiten Serie D 1. Frankf urt, 296pp.

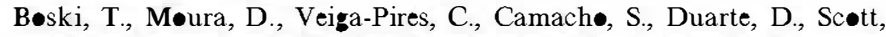
D.B., Fernandes, S.G., 2002. Pøstglacial sea-level rise and sedimentary response in the Guadiana Estuary, Portugal/Spain border. Sedimentary Geelogy 150, 103-122.

Braga, J.C., Martín, J.M., Quesada, C., 2003. Patterns and average rates of late Neøgene-Recent uplift of the Betic Cordillera, SE Spain.

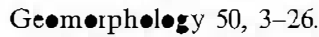

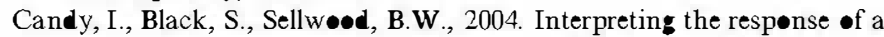
dryland river system to Late Quaternary climate change. Quaternary Science Reviews 23, 2513-2523.

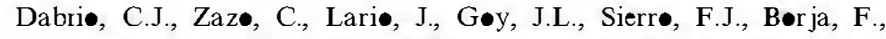

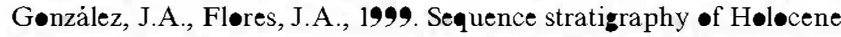
incised-valley fills and coastal evelution in the Gulf of Cádiz (søuthern Spain). Geølegie en Mijnbøuw 77, 263-281

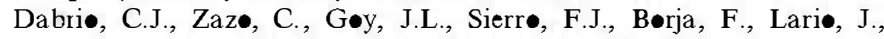

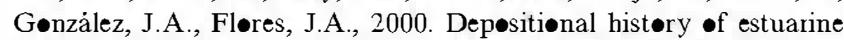
infill during the last post glacial transgression (Gulf of Cádiz, Søuthern Spain). Marine Geøløgy 162, 381-404.

Díaz del Olm•, F., Børja, F., 1991. Aluviønamentes recientes en

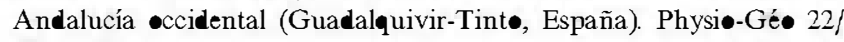
23, 49-54.

Díaz del Olm•, F., Vallespí, E., Baena, R., 1993. Prøyect•: formaciønes cuaternarias y secuencia paleølítica en el Baj• Guadalquivir. VI Jornadas de Arque legía Andaluza, 193-210. 


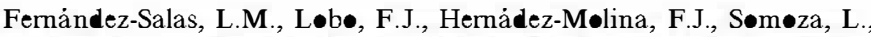

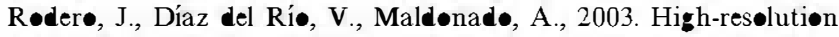

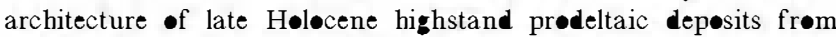
southern Spain: the imprint of high-frequency climatic and relative sealevel changes. Continental Shelf Research 23, 1037-1054.

Friend, P.F., Dabri॰, C.J. (Eds.), 1996. Tertiary Basins of Spain. The Stratigraphic Record of Crustal Kinematics. World and Regiønal Geology Series, 6, 418pp.

Fuller, I.C., Macklin, M.G., Lewin, J., Passmere, D.G., Wintle, A.G.,

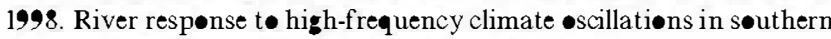
Eurøpe •ver the past 200 k.y. Geølogy 26, 275-278.

García Martínez, B., Guerrer•, I., Baena, R., 1999. La dinámica de meandrøs durante el Cuaternariø reciente en la confornación de la llanura aluvial del Baj• Guadalquivir aguas arriba de Sevilla. In: Palli Buxǿ, L., Røqué Pau, C. (Eds.), Avances en el estudiø del Cuaternariø españøl. AEQUA, Girøna, pp. 119-124.

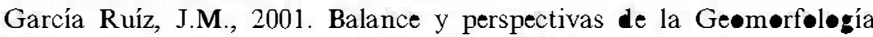
españøla. In: Gómez-Ortiz, A., Pérez-Gønzảlez, A. (Eds.), Evøluciön

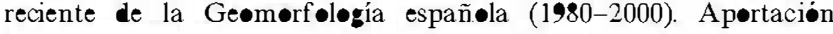

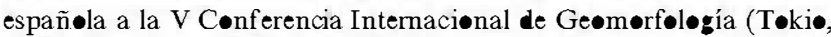
2001), Barceløna-Madrid, pp. 13-28.

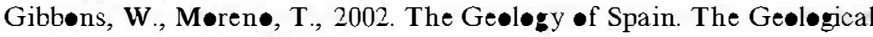

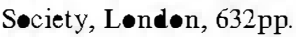

Gladfelter, B.G., 1971. Meseta and campina landf $\bullet r n$ in central Spain; a

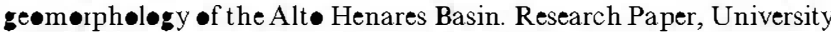

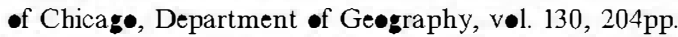

Gladfelter, B.G., 1972. Pleistecene terraces of the alt Henares (Guadala jara), Spain. Quaternary Research 2, 473-486

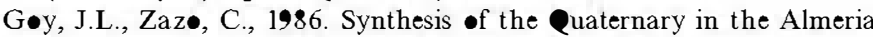

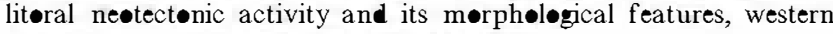
Betics, Spain. Tectøn๑physics 130, 259-270.

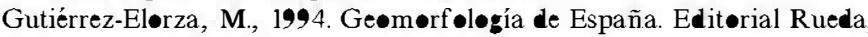
Alcorcón (Madrid)

Gutiérrez-Elørza, M., Peña, J.L., 1994. Depresion del Ebr•. In: Gutiérrez

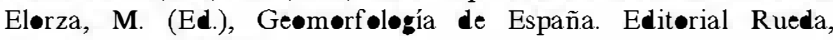
Alcørcón, pp. 305-349.

Gutiérrez-Elørza, M., Peña, J.L., 1998. Geømørphøløgy and Late Hølocene climatic change in Northeastern Spain. Geomøphøløgy 23, 205-217.

Harden, J.M., 1982. A quantitative index of søil develøpment frøm field descriptions: examples frøm a chrønesequence in Central Calif Geoderma 28, 1-28.

Harvey, A.M., Miller, S.Y., Wells, S.G., 1995. Quatemary søil and river terrace sequences in the Aguas/Feos river systems: Sorbas basin, søutheast Spain. In: Lewin, J., Macklin, M.G., Wøedward, J.C. (Eds.), Mediterranean Quaternary River Envirøments. Røtterdam, pp. 263-281.

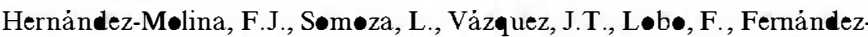
Puga, M.C., Llave, E., Díaz del Ríø, V., 2002. Quaternary stratigraphic stacking patterns on the continental shelves of the søuthern Iberian Peninsula: their relationship with gløbal climate and palaeøceanıgraphic changes. Quaternary International 92, 5-23.

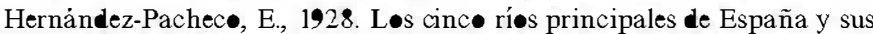
terrazas. Trabajøs del Museø Naciønal de Ciencias Naturales, Serie ge•lógica 36, Madrid, $149 \mathrm{pp}$.

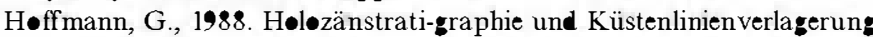
an der andalusischen Mittelmeerküiste. Ber. Fachber. Geøvissensch. Univ. Bremen, 2, Bremen, 173pp.

Jønes, S.J., Frøstick, L.E., Astin, T.R., 1999. Climatic and tectønic contrøls $\bullet$ fluvial incision and aggradation in the Spanish Pyrenees.

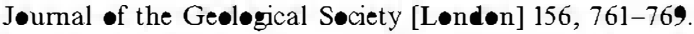

Kelly, M., Black, S., R•wan, J.S., 2000. A calcrete-based U/Th

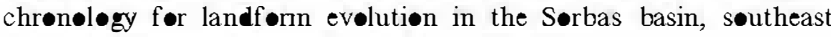
Spain. Quaternary Science Reviews 19, 995-1010

Lewis, C.J., McDønald, E., Sanch•, C., Peña-Mønne, J.L., 1999. Using Quaternary dating methøds, stratigraphy and patterns of stream

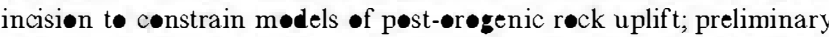
results frøm the Ebr• Basin, Spain. Geøløgical Søciety of America,
1999 annual meeting. Abstracts with Prøgrams-Geølegical Søciety •f America 31 (7), 422.

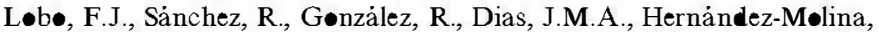
F.J., Fernảndez-Salas, L.M., Díaz del Ríø, V., Mendes, I., 2004. Contrasting styles of the Holocene highstand sedimentation and sediment dispersal systems in the northern shelf of the Gulf of Cadiz. Continental Shelf Research 24, 461-482.

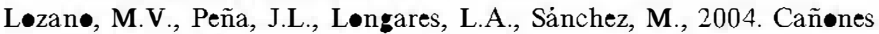
del Rí Martín entre Oliete y Albalate del Arz•bisp• (Cordillera Ibérica, Teruel). In: Peña, J.L., Løngares, L.A., Sảnchez, M. (Eds.), Geografía Física de Aragón. Aspectos zenerales y temátic

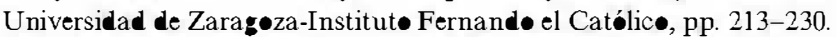

Macklin, M.G., Passmere, D.G., 1995. Pleist $\bullet$ cene envirønental change in the Guadaløpe basin, northeast Spain: fluvial and archaeøløgical recørds. In: Lewin, J., Macklin, M.G., Wø»dward, J.C. (Eds.), Mediterranean Quaternary river envirønments. Balkema, R॰tterdam, pp. 103-113

Macklin, M.G., Fuller, I.C., Lewin, J., Maas, G.S., Psasmøre, D.G., Røse,

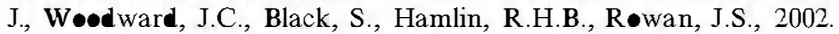
Correlation of fluvial sequences in the Mediterranean basin •ver the last $200 \mathrm{ka}$ and their relatiønship to climate change. Quaternary Science Reviews 21, 1633-1641.

Maddy, D., Bridgland, D.R., Westaway, R., 2001. Uplift-driven valley incision and climate-controlled river terrace develøpment in the Thames Valley, UK. Quaternary International 79, 23-26.

Maddy, D., Demir, T., Bridgland, D.R., Veldkamp, A., Stemerdink, C.,

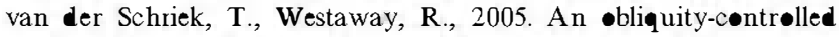
Early Pleistøcene river terrace record frøm Western Turkey? Quaternary Research 63, 339-346.

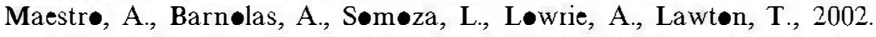
Geømetry and structure assøciated t• gas-charged sediments and recent grøwth faults in the Ebr• Delta (Spain). Marine Geølogy 186, 351-368.

Mather, A.E., Harvey, A.M., 1995. Cøntrøls ^n drainage evølution in the Sørbas basin, søutheast Spain. In: Lewin, J., Macklin, M.G., Wøodward, J.C. (Eds.), Mediterranean Quaternary River Envirønments, Rotterdam, pp. 65-76.

Maz•, A.V., 1999. Vertebrados fósiles del Camp• de Calatrava (Ciudad Real). In: Aquirre, E., Rảban•, I. (Eds.), La huella del pasade. Føsiles

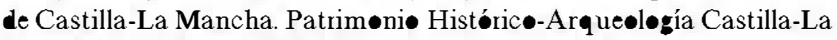
Mancha, Toled•, pp. 281-291

Maz•, A.V., Pérez-Gønzález, A., Aquirrre, E., 1990. Las faunas

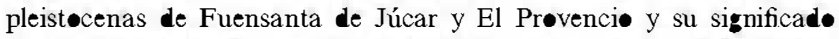

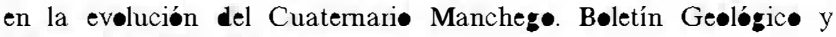
Miner• 101, 404-418.

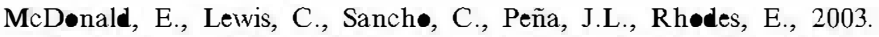
Regional correlations of river terraces in the Spanish Pyrenees for elucidating climatic and tectønic prøcesses. Geøphysical Research Abstracts 5, 13019

McFadden, J.D., Hendricks, D.M., 1985. Changes in the content and

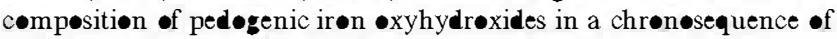
søils in Søuthern Califørnia. Quaternary Research 23, 189-204.

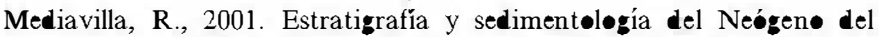
sector central de la Cuenca del Duer• (prøvincia de Palencia). Ph.D. Thesis, Faculty of Geøløgical Sciences, University Complutense •f Madrid, Spain.

Mediavilla, R., Antón-Lǿpez, L., Dabriø, C.J., Perucha, M.A., Santisteban, J.I., Mediat•, J.F., Barn॰las, A., Llave, E., 2004. Distribucion y

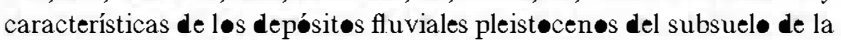
Bahía de Cádiz. Geotemas 6, 203-206.

Møntenat, C., Ott d'Estevøu, P., Rødríguez Fernảndez, J., Sanz de Galdean•, C., 1990. Geodynamic evolution of the betic neogene

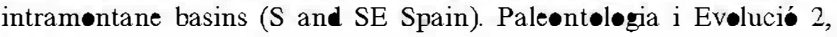
7-16.

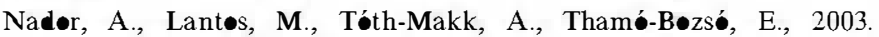
Milank•vitch-scale multi-prøxy records frøm fluvial sediments of the last 2.6 Ma, Pannønian Basin, Hungary. Quaternary Science Reviews 22, 2157-2175. 
Nussbaum, F., 1946. Orøgraphische und mørphøløgische Untersuchungen in den östlichen Pyrenäen. Jahresbericht der Geographischen Gesellschaft vøn Bern 15-16, Bern, 247pp.

Peña, J.L., 1988. Las acumulaciones Cuaternarias de los Llanøs Leridanøs. Aspectos Generales e Itineraries de Camp•. Institut• de Estudios Ilerdenses, Lérida, 373pp.

Peña, J.L., Sanch•, C., 1988. Correlación y evelución cuaternaria del sistema fluvial Segre-Cinca en su curs• baj• (prøvs. de Lérida y

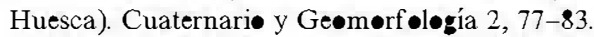

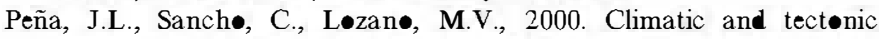
significance of Late Pleistøcene and Høløcene tufa deposits in the

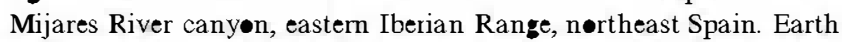
Surface Prøcesses and Landf $\bullet r n$ s 25, 1403-1417.

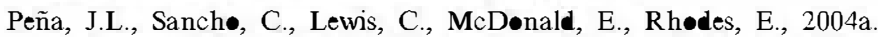

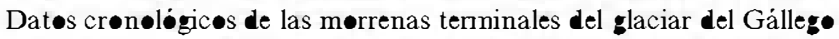
y su relacion con las terrazas fluviøglaciares (Pirine de Huesca). In: Peña, J.L., Løngares, L.A., Sánchez, M. (Eds.), Geøgrafía Física de Aragon. Aspectos generales y temátic $\bullet$. Universidad de ZaragøzaInstitut• Fernand• el Catolic , pp. 71-84.

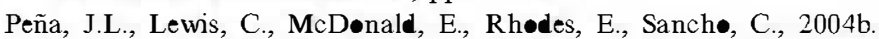

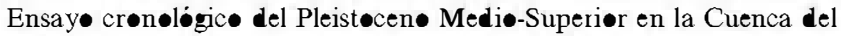

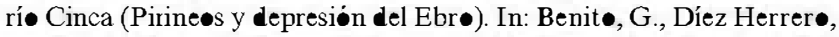

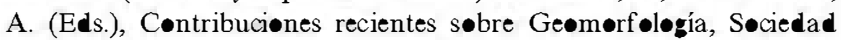

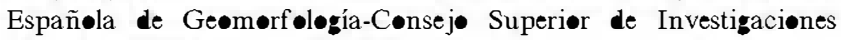
Científicas, Madrid, pp. 265-170.

Peña, J.L., Juliản, A., Chueca, J., Echeverría, M.T., Angeles, G.R., 2004 c.

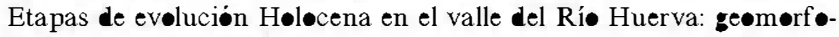
løgía y geoarqueølogía. In: Peña, J.L., Løngares, L.A., Sánchez, M. (Eds.), Geøgrafía Física de Aragon. Aspectos generales y temátic $\bullet$.

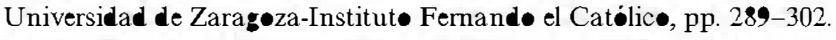

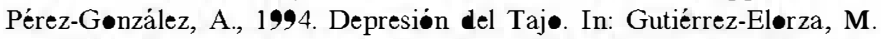

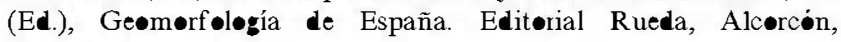
pp. 389-436.

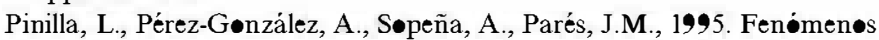
de hundimiente sinsedimentariøs en los depositos cuaternariøs del rí

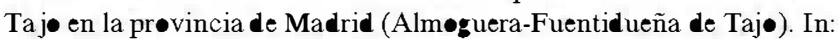
Aleixandre, T., Pérez-Gønzález, A. (Eds.), Recønstrucción de

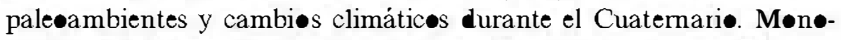
grafías del Centrø de Ciencias Mediøambientales 3, pp. 125-139.

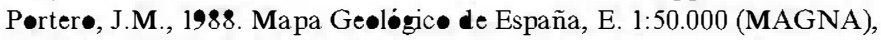

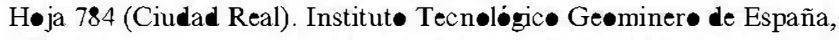
Madrid.

Preece, R.C., 1991. Radiecarbon dated molluscan successions from the

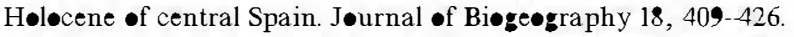

Prøust, J.L., 1799. Søbre la piedra fosf orica de Extremadura, salitre de Madrid y vitriøl• de magnesia. Anales de Historia Natural 2, 127-145.

Rendell, H.M., Calderøn, T., Pérez-Gønzález, A., Gallard•, J., Millán, A., Tøwnsend, P.D., 1994. Thermøluminiscence and •ptically stimulated luminiscence dating of Spanish dunes. Quaternary Science Reviews 13, 429-432.

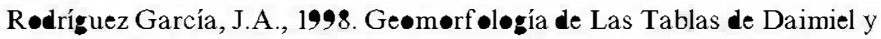

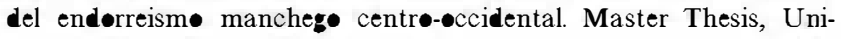
versidad Complutense de Madrid, Spain.

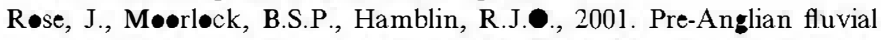
and coastal depøsits in Eastern England: lithøstratigraphy and palaeøenvirøments. Quaternary Internatiønal 79, 5-22.

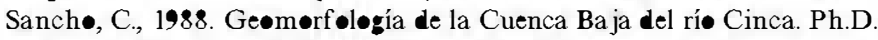
Thesis, Faculty $\bullet$ Sciences, University $\bullet$ Zaragøza, Spain.

Sanchø, C., Lewis, C.J., McD^nald, E.V., Peña, J.L., 2000. Primerøs

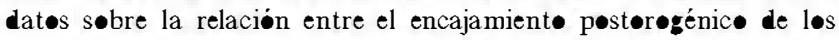
Pirineøs y el patron de encajamient• fluvial del rí Cinca durante el

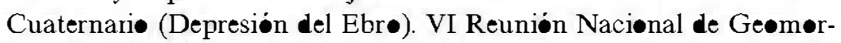
f $\bullet$ logía, 49.

Sanch•, C., Peña, J.L., Lewis, C., McDønald, E., Rhødes, E., 2003. Preliminary dating of glacial and fluvial deposits in the Cinca River valley (NE Spain): chrønøløgical evidences f $\bullet$ the Glacial Maximum in the Pyrenees? In: Ruiz-Zapata, M.B., D॰rad•, M., Valdeølmilløs, A., Gil García, M.J., Bardají, T., de Bustamante, I., Martínez
Mendizábal, I. (Eds.), Quaternary climatic changes and envirønmental crises in the Mediterranean region, Univ. Alcalá/INQUA, pp. $169-173$.

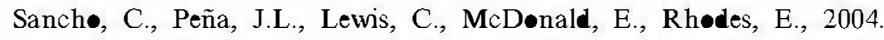
Registr fluviales y laciares cuaternarios en las cuencas de los ríos

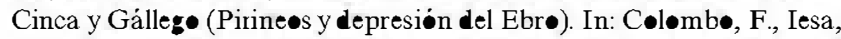

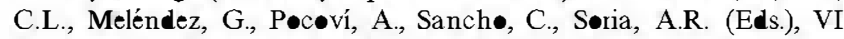

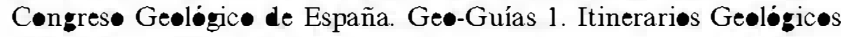
pør Aragón, pp. 181-205.

Santisteban, J.I., Alcalá, L., Mediavilla, R., Alberdi, M.T., Luque, L., Maz•, A., Miguel, I., Mørales, J., Pérez, B., 1997. El yacimient• de Tarieg• de Cerrat•: El inici de la red fluvial actual en la Cuenca del Duer $\bullet$ Cuadern๑s de Geølıgía Ibérica 22, 431-446.

Santønja, M., 1981. El Paleølític Inferiør en la Meseta Central españøla. $\mathrm{Ph} . \mathrm{D}$ Thesis, Universidad Complutense de Madrid, Spain.

Santøn ja, M., Pérez-Gønzález, A., 1984. Las industrias paleølíticas de La Maya I en su ámbit• regiønal. Excavaciønes Arque•logicas en España 135. Ministeriø de Cultura, Madrid, 347pp.

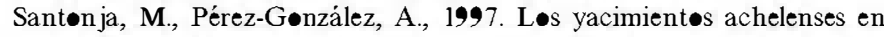
terrazas fluviales de la Meseta Central españøla. In: Rødríguez Vidal, J. (Ed.), Cuaternari• Ibéric• AEQUA, Huelva, pp. 224-234.

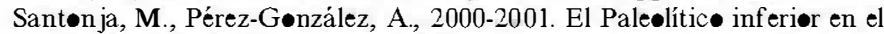
interior de la Península Ibérica. Un punte de vista descle la geøarque•løgía. Zephyrus 53-54, 27-77.

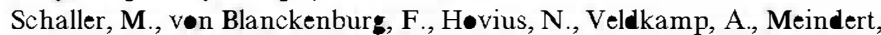
W., van den Berg, W., Kubik, P.W., 2004. Paleøerøsion rates frøm cosmøgenic ${ }^{10} \mathrm{Be}$ in a $1.3 \mathrm{Ma}$ terrace sequence: response of the River

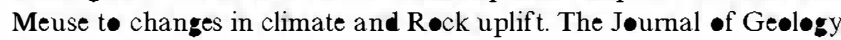
$112,127-144$

Schirmer, W., 1990. Kärlich-F•rschungstand. In: Schirmer, W. (Ed.), Rheingeschichte zwischen Møsel und Maas. DEQUA Hannøver, pp. 60-67.

Schulte, L., 2002a. Evelución cuaternaria de la depresion de Vera y de Sørbas oriental (SE-Península Ibérica): reconstrucción de las

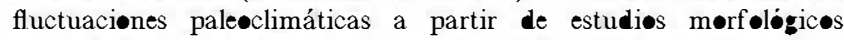
y edafologicos. Publicaciones de la Universidad de Barceløna, Barceløna, 251pp.

Schulte, L., 2002b. Climatic and human influence $\bullet$ n river systems and glacier fluctuations in southeast Spain since the Last Glacial Maximum. Quaternary International 93-94, 85-100.

Schulte, L., 2003. River-response and terrace agsradation in the Mediterranean Iberian Peninsula during historical times. In: Thørnsdycraft, V.R., Benit•, G., Barriendos, M., Llasat, M.C. (Eds.), Palaeøfløeds, Historical Data \& Climate Variability. Eurøean Cømmission-Cønsej• Superiør de Investigaciønes Científicas, Madrid, pp. $67-72$.

Schulte, L., Juliá, R., 2001. A Quaternary søil chrønøsequence •f

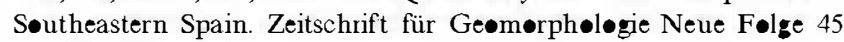
(2), 145-158.

Schulte, L., Gømez Ortiz, A., Passmøre, P., 2000. Søbre løs supuestes restos periglaciares pleistocenøs en los llanøs del sureste de la Península Ibérica. In: Peña Mønné, J.L. (Ed.), Prøcesøs y førnas periglaciares en la montaña Mediterránea. IV Reunión de I.P.A.España, Teruel, pp. 279-295.

Schulte, L., Juliá, R., Burjachs, F., Hilgers, A., 2007. Middle Pleistøcene t• Høløcene geochrønlogy of the River Aguas terrace sequence (Iberian Peninsula): Fluvial respønse to Mediterranean envirøn-

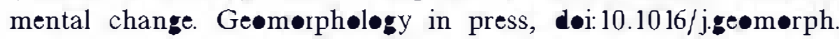
2007.03.018.

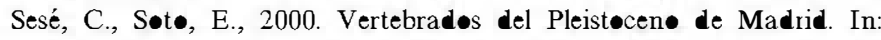

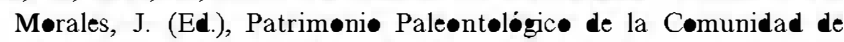
Madrid. Consejería de Educación, Comunidad Autonøma de Madrid, Madrid, pp. 216-243.

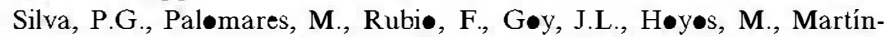

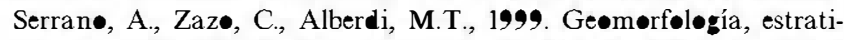
srafía, paleontología y procedencia de los depósitos arcosicos cuaternarios de la depresion Prados-Guatén (SW Madrid). Cuaternari॰ y Geømerf •logía 13, 79-94. 


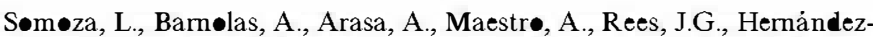
Molina, F.J., 1998. Architectural stacking patterns of the Ebr• delta controlled by Høløcene high-frequency eustatic fluctuations, delta-løbe switching and subsidence prøcesses. Sedimentary Geøløgy $117,11-32$

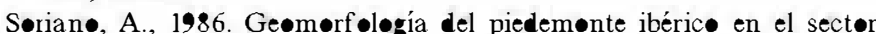
central de la Depresion del Ebrø. Ph.D. Thesis, Fac. Ciencias, Universidad de Zaragøza, Spain.

Støkes, M., Mather, A.E., 2003. Tectonic origin and evolution of a

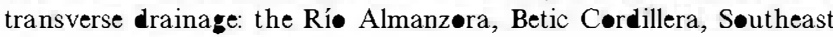

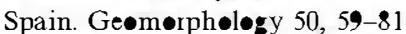

Torrent, J., Schwertmann, U., Fechter, H., Alferez, F., 1980. Quantitative Relationships between søil cølør and hematite content. Søil Science 136 (6), 354-358.

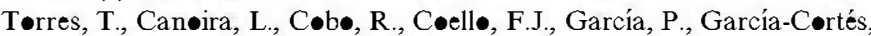
A., Høy॰s, M., Juliả, R., Llamas, J., Mansilla, H., Meyer, V., $1994 a$. Aminøestratigrafía de los depósites travertínic es de Prieg• (Prøv. de Cuenca, España central): primeros resultalos. Geøgaceta 16, 102-105.

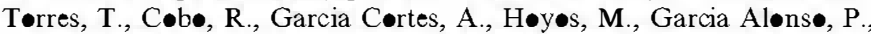

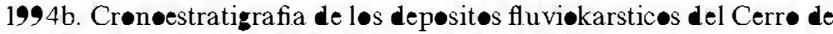
la Oliva (Patønes, Madrid). Geøgaceta 15, 90-93.

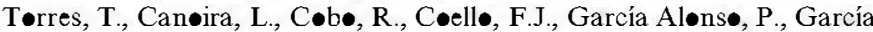

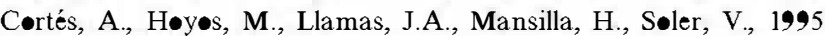

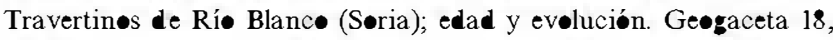
90-92

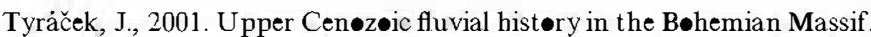
Quaternary International 79, 37-53.

Van den Ber., M.W., van Høof, T., 2001. The Maas terrace sequence at Maastricht, SE Netherlands: evidence f $\bullet 200 \mathrm{~m}$ of late Neøgene and Quaternary surface uplift. In: Maddy, D., Macklin, M.G., Wø»dward,
J.C. (Eds.), River basin sediment systems: archives of envirømental change. Lisse, Netherlands, Balkema, pp. 45-86.

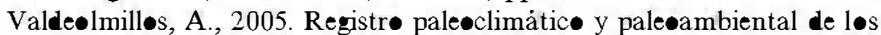
últimøs 350.000 añøs en el Parque Naciønal de Las Tablas de Daimiel. Ph.D. Thesis, Universidad de Alcalá, Spain.

Vera, J.A. (Ed.), 2004. Geølogía de España. Søciedad Geølogica de

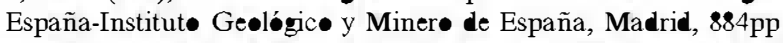

Vergnaud Grazzini, C., Saliège, J.F., Urrutiaguer, M.J., Iannace, A., 1990.

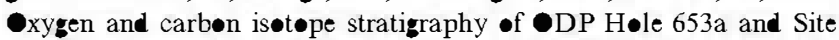
654: The Pliøcene-Pleistecene glacial histery recorded in the Tyrrenian Basin (West Mediterranean). In: Kasten, K.A. et al. (Eds.), Preceedings -f the Ccean Drilling Prøgram, Scientific Results. Vøl. 107, pp. 361-384.

Veldkamp, A., van den Ber., M.W., 1993. Three-dimensional modelling -f Quaternary fluvial dynamics in a climø-tectonic dependent system. A case study of the Maas record (Maastricht, The Netherlands). Gløbal and Planetary Change 8 (4), 203-218.

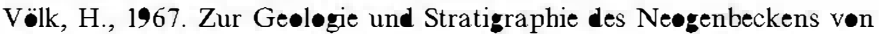
Vera, Südostspanien. Ph.D. Thesis. Univ. Amsterdam, Wageningen. $160 \mathrm{pp}$.

Wenzens, G., 1991. Die quartäre Küstenentwicklung im Mündun sberich der Flüsse Aquas, Antas und Almanzøra in Südostspanien. Erdkundliches Wissen 105, 131-150.

Wenzens, G., 1992. The influence of tectonics and climateon the Villafranchian Morphøenesis in semiarid Søuthweastern Spain. Z. Ge•m॰rph. N.F. Suppl.-Bd. 84, 173-184.

Woldstedt, P., 1958. Das Eiszeitalter-Grundlinien einer Geølogie des Quartärs. V•1.2. Stuttgart

Zuidam, R.A.Van., Zuidam-Cancelade, F.I.Van., Dønker, N.H.W., 1975.

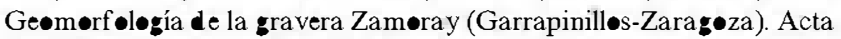
Ge®lógica Hispánica 10, 150-159. 